\title{
Phytoplankton dynamics in a changing Arctic Ocean
}

\author{
Mathieu Ardyna $\oplus^{1,2 \bowtie}$ and Kevin Robert Arrigo ${ }^{1}$
}

\begin{abstract}
Changes in the Arctic atmosphere, cryosphere and Ocean are drastically altering the dynamics of phytoplankton, the base of marine ecosystems. This Review addresses four major complementary questions of ongoing Arctic Ocean changes and associated impacts on phytoplankton productivity, phenology and assemblage composition. We highlight trends in primary production over the last two decades while considering how multiple environmental drivers shape Arctic biogeography. Further, we consider changes to Arctic phenology by borealization and hidden under-ice blooms, and how the diversity of phytoplankton assemblages might evolve in a novel Arctic 'biogeochemical landscape'. It is critical to understand these aspects of changing Arctic phytoplankton dynamics as they exert pressure on marine Arctic ecosystems in addition to direct effects from rapid environmental changes.
\end{abstract}

T he Arctic climate is in the process of irretrievably moving into a new state, forced by increases in atmospheric levels of carbon dioxide and other greenhouse gases ${ }^{1,2}$. As a result, the years 2010 to 2015 were the warmest five years on record in the Arctic, with a dramatic $5{ }^{\circ} \mathrm{C}$ increase in January since 1900 $\left(\right.$ ref. ${ }^{1}$ ). This heat trapped by greenhouse gases triggers a cascade of feedbacks that collectively amplify Arctic warming ${ }^{1}$. Over the next two decades, an additional $4-5{ }^{\circ} \mathrm{C}$ increase is predicted in the autumn and winter across the Arctic in conjunction with the projected increase in greenhouse gases concentrations ${ }^{1}$. This expected temperature increase is more than twice that projected for the global average.

Associated with the increased temperatures, the Arctic Ocean is experiencing radical modifications in its hydrographic properties (that is, freshwater, salt and heat content) and in its overall circulation. Driven by increasing inputs from multiple freshwater sources (that is, river inflow, net precipitation and melting sea ice and glaciers), the volume of freshwater in Arctic surface waters has increased by $8,000 \mathrm{~km}^{3}$ (more than $11 \%$ ) compared to the 1980 2000 period $^{1,3}$. Below the surface over much of the Arctic Ocean, a strong halocline layer acts as a barrier separating Atlantic water heat from the cold and fresh upper Arctic waters ${ }^{4,5}$. Increased stability of the Arctic halocline, a potential consequence of climate change, would likely reduce both the vulnerability of sea ice to upward heat fluxes from the ocean interior and the vertical mixing of carbon and nutrients ${ }^{6,7}$.

At the atmosphere-ocean interface, the traditional Arctic icescape is changing largely due to atmospheric forcing and, to a lesser extent, winter ocean heat flux, particularly in the Eurasian Arctic sector 6 . Since the 1970 s, the extent of summer sea ice has decreased by $>40 \%$ (Fig. 1a) and its thickness by $65 \%$, with first-year ice largely replacing the thick multiyear pack ice (Fig. 1b,c) ${ }^{1,8}$. In addition to the increased open-water area and duration that amplify ice albedo feedbacks, sea ice is becoming increasingly fragmented and dynamic, resulting in drastically altered under-ice light fields that significantly impact both pelagic and sympagic (that is, sea-ice-associated) ecosystem dynamics.

Together, these climate-driven changes within the atmosphere, cryosphere and ocean have wide-ranging consequences for Arctic marine ecological dynamics, influencing productivity, species interactions, population mixing and pathogen and disease transmission $^{9-11}$. To advance knowledge of these unique ecosystems in an era of rapid change, here we have synthetized recent developments over the last decade to study phytoplankton dynamics (the base of marine ecosystems) by examining current changes in primary productivity, phenology and assemblage composition, and how these changes could alter the ecology and biogeochemistry of the Arctic Ocean.

\section{Arctic primary production in a changing icescape}

The reduction in sea-ice extent in the Arctic Ocean over the last few decades has resulted in both a longer phytoplankton growing season and increased open-water habitat for phytoplankton growth ${ }^{12-14}$. Consequently, phytoplankton blooms now begin earlier ${ }^{13,15}$ and end later ${ }^{16}$ in the year, and annual net primary production (NPP) in open waters over the entire Arctic Ocean increased 30\% between 1998 and 2012 (ref. ${ }^{17}$ ), the year that summer sea-ice extent reached its historical minimum. This increase in NPP might have been even larger if it were not for a concomitant increase in cloudiness and decrease in light availability over the $\operatorname{Arctic}^{14}$. Over this period, the largest increases in annual NPP were restricted to the interior Arctic shelves (Laptev, Kara and Siberian), where NPP increased 70-112\% over the 15-yr study and sea-ice loss was most severe (4.2-5.4\% $\left.\mathrm{yr}^{-1}\right)$. In contrast, NPP on the outflow shelves showed a much smaller increase ( $8 \%$, Baffin) and even a decrease ( $-15 \%$, East Greenland) in response to much smaller declines in sea-ice cover $\left(0-0.9 \% \mathrm{yr}^{-1}\right)^{17}$.

A more recent satellite-based study ${ }^{18}$ that was extensively validated using a large in situ database has shown that since reaching the minimum sea-ice extent in 2012, the rate of increase in open-water area in the Arctic Ocean has slowed considerably, decreasing from $88,000 \mathrm{~km}^{2} \mathrm{yr}^{-1}$ between 1998 and 2012 to only $620 \mathrm{~km}^{2} \mathrm{yr}^{-1}$ between 2012 and 2018 (Fig. 2a). In addition, the average ice-free period in the Arctic only increased from 147 to 152 open-water days (five days) between 2012 and 2018. Thus, neither the extent of open-water phytoplankton habitat nor the length of the growing season changed significantly during this time. Nevertheless, annual NPP in ice-free waters continued to increase at rate of 6.8 $\mathrm{TgC} \mathrm{yr}^{-1}$ between 1998 and 2018, peaking at $391 \mathrm{TgC} \mathrm{yr}^{-1}$ in 2018

'Department of Earth System Science, Stanford University, Stanford, CA, USA. ${ }^{2}$ Sorbonne Université, CNRS, Laboratoire d'Océanographie de Villefranche,

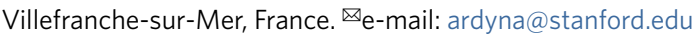


a

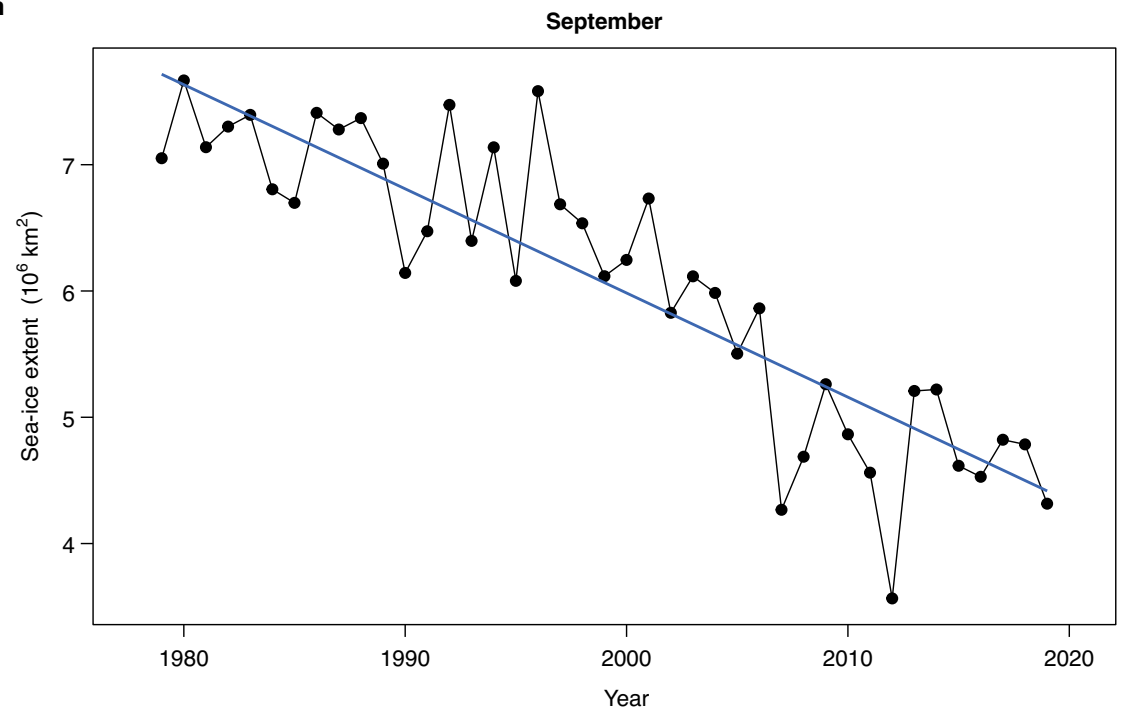

b

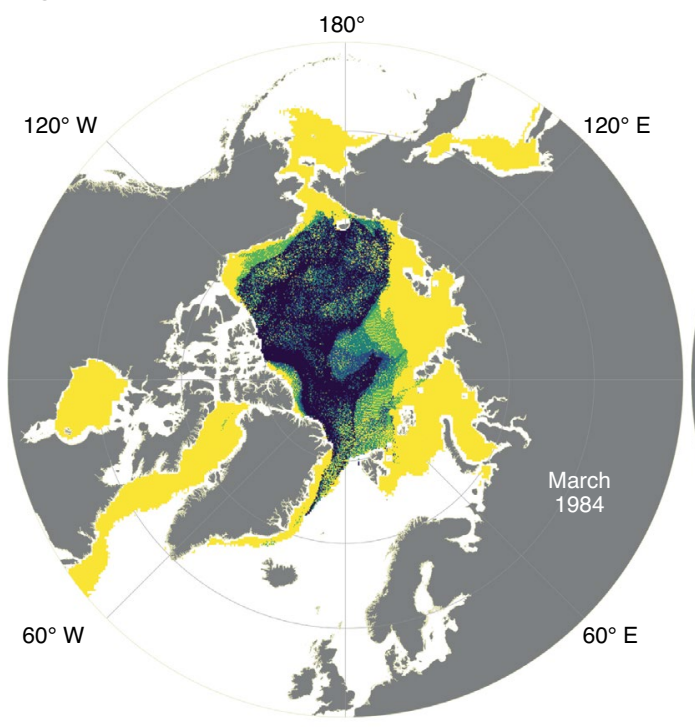

c

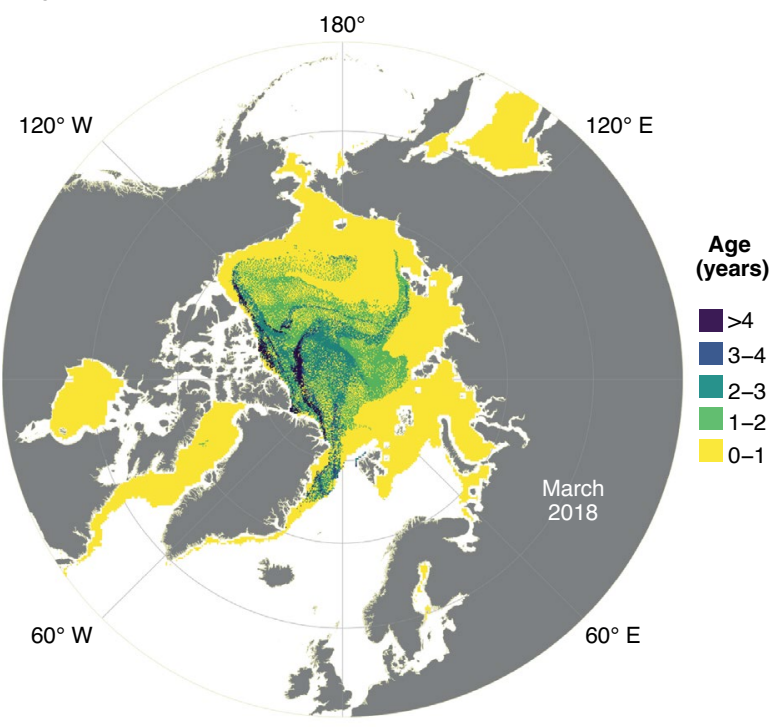

Fig. 1 | Changing sea-ice extent and age. a, Time series of the summer sea-ice extent (in $10^{6} \mathrm{~km}^{2}$ ) from 1979 to $2019 . \mathbf{b}, \mathbf{c}, \mathrm{Maps}_{\mathrm{m}} \mathrm{comparing}$ winter Arctic sea-ice age in 1984 (b) and 2018 (c). The satellite-derived sea-ice data are from the National Snow and Ice Data Center (NSIDC; Cavalieri et al. ${ }^{185}$ and Tschudi et al. $\left.{ }^{186}\right)$.

(Fig. 2c). Notably, despite the flattening in the trend in open-water area between 2012 and 2018, the increase rate in annual NPP over the Arctic during that time period $\left(13.5{\mathrm{TgC} \mathrm{r}^{-1}}^{-1}\right)$ was double that between 1998 and $2012\left(6.4 \mathrm{TgC} \mathrm{yr}^{-1}\right)$. This suggests that the factors controlling annual net primary production changed between the early and late phases of the 1998-2018 time series.

Whereas the increase in annual NPP between 1998 and 2012 was highly correlated to the decline in sea ice and an increase on open-water phytoplankton habitat, the increase in annual NPP between 2012 and 2018 was associated with increased surface chlorophyll $a$ (Chl a) concentrations (Fig. 2b,d). Prior to 2012, concentrations of Chl $a$ across the Arctic Ocean were relatively constant, increasing by only $0.002 \mathrm{mg} \mathrm{m}^{-3} \mathrm{yr}^{-1}$ (or $0.27 \%$ ). However, between 2012 and 2018, mean Chl $a$ concentration in Arctic Ocean surface waters increased at a rate of $4.3 \% \mathrm{yr}^{-1}$, 16 times faster than the rate prior to 2012. The largest increases in Chl $a$ between 1998 and 2018 were measured on the inflow shelves of the Chukchi Sea (26\%) and Barents Sea (61\%), and at the recently exposed shelf break of the Laptev Sea (Fig. 2d). If we assume that increases in $\mathrm{Chl} a$ concentration are indicative of increases in phytoplankton biomass, the latter of which cannot increase without additional nutrients, these results suggest that increased nitrogen $(\mathrm{N})$ supply from either increased vertical mixing near the shelf break or advection from lower latitude waters may be responsible for the NPP increase in ice-free Arctic waters since 2012 (ref. ${ }^{18}$ ). However, we cannot eliminate the possibility that changes in grazing pressure also may have impacted phytoplankton populations, and hence $\mathrm{NPP}^{19-23}$.

\section{Biogeography shaped by changing environmental drivers}

The complexity of Arctic biogeography makes it particularly challenging to fully comprehend the interplay of environmental drivers and their change and impacts on phytoplankton dynamics (Figs. 3 and 4). Here, we attempt to highlight at the regional scale (that is, between inflow, interior and outflow shelves and the central Arctic; following the terminology of Carmack et al. ${ }^{24}$ ) how the 
a

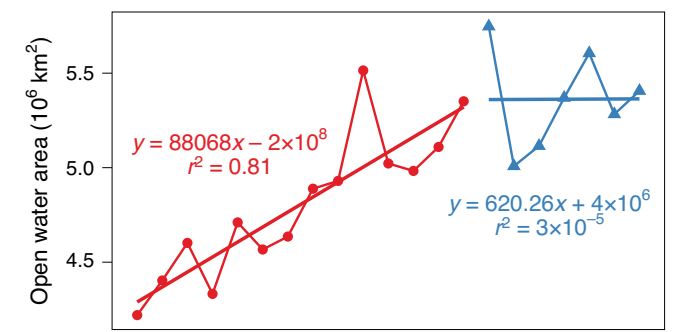

b

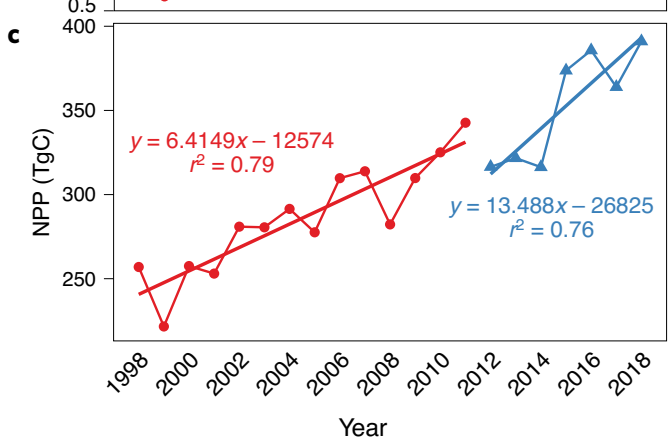

d

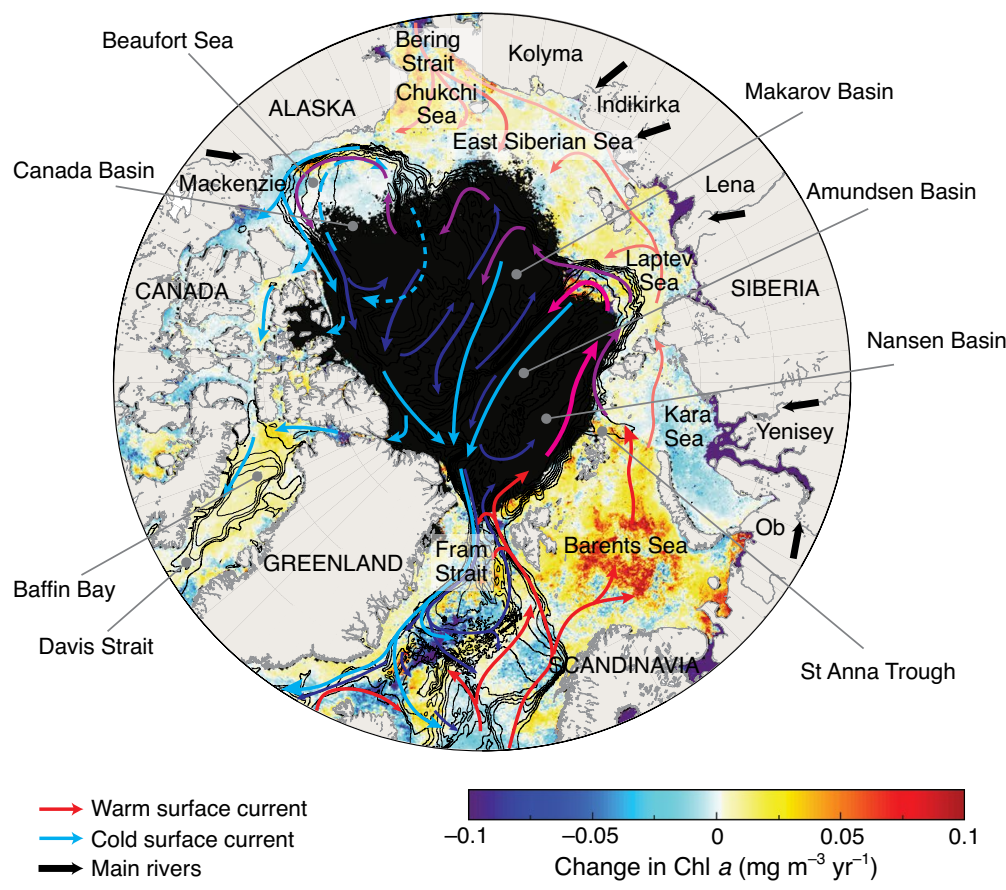

Fig. 2 | Global trends in Arctic primary production over the two last decades. a-c, Annual time series of Arctic Ocean mean open-water area (a), mean $\mathrm{Chl} a$ (b) and NPP (c). The time series is separated into two time periods because from 1998-2012, loss of sea ice was responsible for the increase in NPP for the Arctic Ocean. After that time, the loss of sea ice slowed considerably but NPP continued to increase. This increase from 2012-2018 was due primarily to an increase in phytoplankton biomass, likely because of increased nutrient supplies into Arctic surface water. $\mathbf{d}$, Map showing the rate of change in Chl $a\left(\mathrm{mg} \mathrm{m}^{-3} \mathrm{yr}^{-1}\right)$ between 1998 and 2018. Shown are the dominant Arctic Ocean currents with inflowing relatively warm surface currents (red arrows) and colder surface currents (light-blue arrows), together with intermediate and deep currents (burgundy and dark-blue arrows, respectively; currents modified from Anderson and Macdonald ${ }^{187}$ ). Black arrows indicate the main river inputs and dashed light-blue arrows indicate the deep circulation of the Beaufort Gyre. Figure adapted from Lewis et al. ${ }^{18}$.

major environmental drivers will change and how new ones might emerge in a changing Arctic Ocean.

Nutrient supply and vertical mixing. Nutrient supply (primarily nitrate $^{25,26}$ and, to a lesser extent, silicate ${ }^{27-29}$ and rarely iron ${ }^{30}$ ) drives the biogeography and trophic status (that is, oligotrophic or eutrophic) of the Arctic Ocean, while light availability modulates the rate of NPP within each region ${ }^{29,31,32}$. These key factors (that is, nutrients and light) are in turn regulated by a complex interplay of processes altering stratification and mixing as well as the presence of sea ice and snow cover superimposed on seasonal and latitudinal controls on light availability ${ }^{33}$ (Fig. 3). Winter nutrient inventories show a strong linear relationship with annual NPP via their role in regulating phytoplankton biomass, except for areas where wind-driven and topographically enhanced mixing (that is, driving resuspension and upwelling events) resupply nutrients during the growing season $^{31}$. Locally, depending on the interplay between atmospheric forcing (that is, intensity, duration and direction of the wind stress) and the strength of vertical stratification, the injection of nutrients into surface layers can easily vary by two orders of magnitude across the Arctic Ocean ${ }^{31,34,35}$. Stratification is expected to increase in the Canada Basin $^{36}$ but decrease in other regions (for example, in the Eurasian sector ${ }^{6,37}$; Fig. 4). On the other hand, the loss of sea ice is expected to increase winds and strong wind events by the end of the century due to reduced atmospheric stability resulting from increased temperature and turbulent fluxes ${ }^{38}$. These enhanced atmospheric forcings occur in all seasons but especially in autumn and winter (where they are expected to strengthen by up to $50 \%$ in the central Arctic and peripheral seas ${ }^{38}$. Changing the balance between vertical stratification and atmospheric forcing will be subject to antagonistic and region-specific environmental drivers (that is, advection, mesoscale activity, atmospheric forcing and related processes, such as upwelling) and will ultimately alter phytoplankton dynamics.

Advection at the Arctic gateways. The Arctic marine biome is tightly connected to lower latitudes through the northern Pacific and Atlantic oceans. In inflow shelves (Fig. 3), Atlantic and Pacific waters flow northward through the European Arctic Corridor and the Bering Strait, respectively, carrying heat, nutrients and planktonic organisms to the Arctic Ocean. A twofold increase in North Atlantic current velocities over the last 24 years was recently revealed, explaining decadal variations in the spatial distribution of the coccolithophorid Gephyrocapsa huxleyi (previously called Emiliania huxleyi $i^{39}$ ), a tracer for temperate ecosystems ${ }^{40-42}$. Bio-advection, rather than the previously assumed water temperature, may be the major mechanism responsible for poleward intrusions of southern species like coccolithophores ${ }^{40}$ (and potentially the picocyanobacteria 

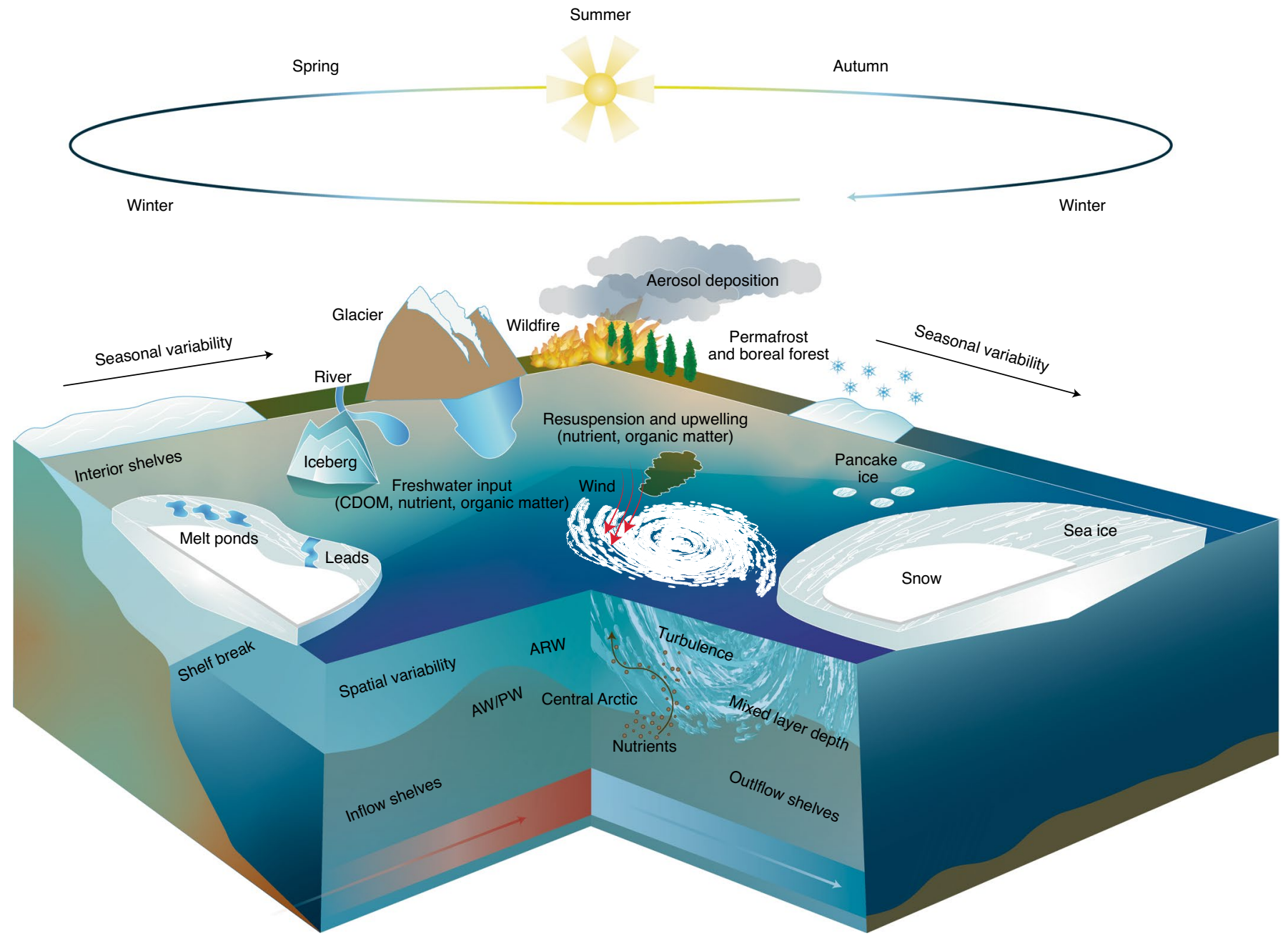

Fig. 3 | Environmental drivers shaping Arctic phytoplankton dynamics. The oceanic, terrestrial and atmospheric compartments are displayed over an annual cycle. The interconnectivity of the seasonal (that is, horizontal dimension) and the spatial (that is, vertical dimension) variability emerges as a framework to understand the mosaic of the environmental drivers shaping Arctic phytoplankton dynamics. Water masses are also indicated. ARW, Arctic waters; AW, Atlantic waters; PW, Pacific waters; CDOM, coloured dissolved organic matter.

Synechococcus ${ }^{43}$ ). A similar increase in poleward advection of Pacific waters through the Bering Strait suggests that the shrinking Arctic domain may be prone to intrusions of temperate species at both of the Arctic gateways ${ }^{44}$. However, as described previously, advective transport can result in a case of life or death in the Arctic Ocean depending on the ability of these invasive species to survive strong environmental gradients, low water temperature and long periods of darkness ${ }^{45}$. Advective processes alter mostly lower trophic levels that have a limited capacity for mobility (for example, phytoplankton, zooplankton and some fish), and consequently can impact entire marine ecosystems by shifting species distributions and modifying interactions at higher trophic levels ${ }^{46-48}$. Considering the role of bio-advection in ecological models (that is, trait-based and niche-based approaches) will be necessary to improve predictions of future ecosystem shifts in the context of climate change ${ }^{49}$.

Not only are the inflow shelves shaped by advective processes, the outflow shelves (for example, the Canadian Arctic ArchipelagoBaffin Bay complex and the East Greenland shelf) also respond strongly, and likely differently, to upstream changes in sea-ice dynamics and export, hydrographic structure and biogeochemical cycles ${ }^{33,50}$. In both northern Baffin Bay and the East Greenland shelf, changes in stratification and sea-ice dynamics (that is, extent and export) shape spring bloom phenology and nutrient inventories for the phytoplankton growing season ${ }^{51,52}$. On the East Greenland shelf, the magnitude of sea-ice export can explain spatial shifts in the boundaries between stratification regimes (that is, haline- versus temperature-based stratification ${ }^{53}$ ) and different phytoplankton dynamics (for example, more intense and early phytoplankton blooms in haline-based stratification). However, strong haline-based stratification reinforced by increasing freshwater input in the North Water Polynya within northern Baffin Bay, a biologically productive oasis for marine mammals and birds, resulted in a sharp decline in phytoplankton biomass (especially centric diatoms) and NPP during 1999-2011 (ref. ${ }^{54}$ ). In addition, early season nutrient consumption by phytoplankton blooms under the sea ice and/or at the sea-ice edge in waters that are advected into North Baffin Bay can contribute to this overall productivity decline along with a change in the algal community toward smaller cells ${ }^{54}$. Assessing the impacts of climate change on the inflow and outflow shelves clearly requires proper consideration of the connectivity between the northern Pacific and Atlantic Oceans and the central Arctic Ocean.

Land-ocean continuum. Through the land-ocean continuum, peripheral environmental pressures play an increasing role in the functioning of Arctic marine biogeochemical cycles. In particular, increased inflow of glacial meltwater and freshwater from fjords 


\begin{tabular}{|c|c|c|c|c|c|}
\hline Environmental driver & $\begin{array}{l}\text { Inflow } \\
\text { shelves }\end{array}$ & $\begin{array}{l}\text { Interior } \\
\text { shelves }\end{array}$ & $\begin{array}{l}\text { Outflow } \\
\text { shelves }\end{array}$ & $\begin{array}{l}\text { Central } \\
\text { Arctic }\end{array}$ & $\begin{array}{l}\text { Impact for phytoplankton } \\
\text { dynamics }\end{array}$ \\
\hline Sea-ice extent & +++ & +++ & +++ & +++ & Increasing light availability \\
\hline Sea-ice thickness & ++ & ++ & ++ & +++ & $\begin{array}{l}\text { Increasing under-ice light } \\
\text { availability }\end{array}$ \\
\hline Temperature & +++ & + & + & + & Increasing metabolism activity \\
\hline $\begin{array}{l}\text { Freshwater inputs } \\
\text { (rivers, fjords, meltwater) }\end{array}$ & + & +++ & ++ & +++ & $\begin{array}{l}\text { Increasing the vertical } \\
\text { stratification, more lateral but } \\
\text { less vertical nutrient inputs }\end{array}$ \\
\hline Vertical stratification & & & & & $\begin{array}{l}\text { Increasing (decreasing) the } \\
\text { vertical stratification, less } \\
\text { (more) vertical nutrient inputs }\end{array}$ \\
\hline Wind speed and storminess & ++ & ++ & ++ & ++ & $\begin{array}{l}\text { More storminess, more } \\
\text { vertical nutrient inputs }\end{array}$ \\
\hline Aerosol deposition & $?$ & $?$ & $?$ & $?$ & $\begin{array}{l}\text { Nutrient fertilization of } \\
\text { surface waters }\end{array}$ \\
\hline Acidification & +++ & ++ & + & + & Less calcification \\
\hline
\end{tabular}

Fig. 4 | Synthesis of selected observed regional environmental changes in the Arctic Ocean. For each region, environmental changes and impacts for Arctic phytoplankton are shown. For environmental changes, yellow and green colouring indicates an increase and decrease, respectively. The confidence level $(+)$ refers to the confidence in attributing observed changes for phytoplankton dynamics. Question marks (?) indicate that the evaluation has not yet been assessed at the regional scale, or that there is insufficient evidence for the evaluation.

and river mouths (Fig. 3) will dramatically alter coastal biogeochemical cycles. Outflow from fjords impact near-shore nutrient inventories (phosphorus, silicate and iron) $)^{55-58}$ and can even fuel large summer phytoplankton blooms ${ }^{21}$. Interestingly, in the Greenlandic fjords, two types of glaciers (that is, marine- and land-terminating glaciers) have contrasting effects on phytoplankton productivity. Rising subsurface meltwater plumes originating from marine-terminating glaciers trigger upwelling of nutrient-rich deep water, which supports high summer phytoplankton productivity ${ }^{59}$. On the other hand, fjords with land-terminating glaciers or anomalously strong freshening events lack such upwelling processes and result in increased stratification, which lowers productivity ${ }^{59,60}$. As a result, future transitions from marine to terrestrial glaciers, and the associated increases in stratification intensity, will noticeably alter local productivity with potentially cascading effects on trophic levels.

The increase in pan-Arctic river inputs, driven by an intensifying Arctic water cycle, is also expected to affect marine coastal biogeochemical cycles. However, while nutrient supply by rivers can be locally important, it does not seem to support a significant fraction of Arctic NPP ${ }^{31}$. For example, field observations and modelling at the mouth of the Mackenzie River in the Beaufort Sea have shown that inorganic $\mathrm{N}$ from rivers was contained and entirely consumed within a few tens of kilometres of delta outlets ${ }^{61-64}$, creating potential near-coastal biological hotspots. On the other hand, large river outflow will intensify the freshwater stratification and light-absorbing properties (that is, mainly via coloured dissolved organic matter and, to a lesser extent, particles ${ }^{65,66}$ ). However, recent findings suggest that it does not appear to decrease phytoplankton productivity by limiting wind-driven shelf-break upwelling and decreasing light transmission ${ }^{18}$. Shelf-break waters have been shown to harbour massive phytoplankton blooms $\mathrm{s}^{67,68}$ and are likely to form an 'Arctic Green Belt' ${ }^{\prime}$ as they become increasingly sea-ice-free and are exposed to atmospheric forcing ${ }^{50}$.
Wildfire and Arctic aerosol deposition. In recent years, an unexpected increase in the frequency of wildfire events has been observed in summer in boreal forest ${ }^{69}$ and tundra ecosystems at a pan-Arctic scale ${ }^{70}$. Although wildfires are common in the northern hemisphere, they are becoming particularly unusual by their latitude, duration and intensity ${ }^{69,70}$. Such extreme wildfire activity has been clearly correlated to high temperatures and dry conditions, and increased atmospheric disturbances (that is, thunderstorms) $)^{71}$. Increased wildfire activity in these areas can release large amounts of carbon (C) and $\mathrm{N}$ to the Arctic atmosphere ${ }^{72,73}$ and, by deposition, could alter sea-ice optical properties and, potentially, marine biogeochemical cycles (Fig. 3). Light-absorbing particles (including black $\mathrm{C}$ ) is well recognized to be an efficient absorber of solar radiation $^{74}$, and its deposition onto, or incorporation into, snow and sea ice can decrease the surface reflectance and increase melt rates ${ }^{74-77}$. More uncertain is whether wildfire-derived aerosols can be used as a new source of nutrients (mainly $\mathrm{N}$ species) in the summer, when $\mathrm{N}$ limits the Arctic phytoplankton NPP. Estimates of atmospheric nutrient deposition are scarce in the Arctic Ocean, but some global modelling budgets suggest that $\mathrm{N}$ and phosphorus inputs are $\operatorname{low}^{78-80}$. Further evaluation is clearly needed to quantify and incorporate these intensifying climate-driven changes in Arctic biogeochemical models (Fig. 4).

Ocean acidification. Some of the fastest rates of ocean acidification have been recorded in the Arctic Ocean due primarily to the higher capacity of cold water to absorb $\mathrm{CO}_{2}$, but also due to inputs from river run-off and ice melt and the inflow of naturally low $\mathrm{pH}$ waters from the Pacific ${ }^{81}$. However, the severity of acidification is not homogeneous across the Arctic Ocean, resulting in high temporal and spatial variability ${ }^{82-84}$ (Fig. 4). Overall, Arctic and subarctic phytoplankton communities seem to be relatively resilient to ocean acidification, with no significant change in productivity and little change in species assemblages under enriched scenarios up to 
$1,000 \mu$ atm $\mathrm{pCO}_{2}$ (refs. ${ }^{85-87}$ ). Contrasting responses between species, however, seem to be characteristic of more acidic subarctic and Arctic waters ${ }^{81}$. For example, small picoeukaryotes seem to benefit from higher $\mathrm{pCO}_{2}$ (refs. ${ }^{88,89}$ ), while prymnesiophytes (including coccolithophores) are generally negatively impacted ${ }^{90,91}$, and varying responses are noted in diatoms ${ }^{85-87,92}$. Predicting the complexity of the biological effects of ocean acidification-in particular, on Arctic phytoplankton dynamics (given varying species, life cycle stage, location and seasonal responses) as well as the phytoplankton-zooplankton interactions-remains poorly constrained and poorly understood ${ }^{61}$.

\section{A new non-traditional Arctic phenology}

The growth of phytoplankton at high latitudes is generally thought to begin in open waters of the marginal ice zone (MIZ) once the highly reflective sea ice ${ }^{93,94}$ retreats in spring, as solar elevation increases and surface waters become stratified by the addition of sea-ice melt water ${ }^{9-98}$. In fact, virtually all recent large-scale estimates of NPP in the Arctic Ocean assume that phytoplankton NPP in the water column under sea ice is negligible $e^{14,17,26,99-101}$. Accordingly, phytoplankton blooms in Arctic waters have been considered to be tightly coupled to the timing of sea-ice retreat ${ }^{15,17,96}$.

Changing spring algal dynamics blooms. Recent observations contradict this paradigm that waters beneath the consolidated ice pack harbour little planktonic life. High concentrations of phytoplankton beneath Arctic sea ice have been reported in areas as widespread as Resolute Bay ${ }^{102-108}$, north of Svalbard ${ }^{108,109}$, Baffin Bay ${ }^{88,108}$, the Greenland Sea ${ }^{110}$, the Barents Sea ${ }^{111,112}$, the Laptev Sea ${ }^{97,113}$ and the Chukchi Sea ${ }^{67,68,108,114,115}$ (Fig. 5a-c). The largest and most well documented of these blooms was observed in the Chukchi Sea beneath fully consolidated sea ice ${ }^{67,68}$. Physiological characteristics of the phytoplankton beneath the ice on the Chukchi shelf in early spring indicate that they were 'primed' to bloom once light levels became high enough to support net photosynthesis ${ }^{116}$. At their peak, these under-ice phytoplankton blooms (UIBs) reached Chl $a$ concentrations in excess of $20 \mathrm{mg} \mathrm{m}^{-3}$ and extended from the ice-water interface to a depth of $25-70 \mathrm{~m}$ and from the ice edge to $>100 \mathrm{~km}$ into the ice pack. The algal biomass associated with these features rivalled that of the most productive ocean ecosystems on Earth ${ }^{67}$.

The observation of intense UIBs beneath fully consolidated sea ice has necessitated a re-examination of many aspects of Arctic marine ecology and biogeochemistry. Because these UIBs are invisible to satellite sensors, recent estimates of annual NPP in waters where UIBs develop may be at least an order of magnitude too $l_{0 w}{ }^{67}$, indicating that seasonally ice-covered waters on Arctic continental shelves have the potential to support vastly higher rates of NPP than has been attributed to them in the past ${ }^{14,17,101}$. In addition, the presence of UIBs shift maximum nutrient consumption and NPP to earlier in the season and farther into the ice pack relative to MIZ blooms. This is important because the timing and location of NPP and associated zooplankton grazing can directly influence the partitioning of organic $\mathrm{C}$ between the upper water column and benthic communities, and thus the efficiency of the biological pump and $\mathrm{C}$ sequestration ${ }^{117}$. Furthermore, in productive Arctic waters where diatoms dominate, food webs tend to be short and even small changes in NPP export pathways can have large cascading effects on higher trophic level organisms ${ }^{118}$. Therefore, it is important to determine how export rates of newly fixed $\mathrm{C}$ and the degree of benthicpelagic coupling will respond to a shift in location and timing of peak rates of NPP from the MIZ ${ }^{119,120}$ to deeper within the ice pack.

'Borealization' of Arctic phytoplankton phenology. Given the ongoing changes in phytoplankton phenology, the 'polar' paradigm of a single annual phytoplankton bloom and subsequent sedimentation of organic matter needs to be revised. Not only has the start of the growing season been profoundly accelerated, but the end of the growing season has been markedly delayed (Fig. 5) ${ }^{121}$. This finding supports an ongoing borealization of the Arctic Ocean and represents a paradigm shift with respect to Arctic Ocean NPP that is likely to impact both ecosystems and biogeochemical cycles in unpredictable ways. For example, a new phenological feature, a secondary (usually autumn) phytoplankton bloom, is developing in parts of the Arctic Ocean ${ }^{16,122-125}$. Although secondary blooms were already prevalent in sea-ice-free regions of the Eurasian Arctic sector influenced by Atlantic waters ${ }^{42,126}$, they are now developing in seasonally ice-covered regions of the Arctic Ocean due to concomitant delayed freeze-up (greater light availability) and increased exposure of the sea surface to wind stress (wind-driven mixing brings nutrients to the surface ${ }^{29,127}$ ). However, these secondary blooms are necessarily restricted to low Arctic latitudes where stratification is not sufficient to inhibit wind-driven mixing (Fig. 5c), and the growing season is long enough to allow phytoplankton growth during any vertical mixing events (Fig. 5b,c). In a changing Arctic Ocean, the spring bloom will undoubtedly remain the major annual NPP event for $\mathrm{C}$ export to higher trophic levels and sequestration in the deep ocean and sediments ${ }^{121,127,128}$. However, changes in phytoplankton phenology or additional pulses of phytoplankton NPP may alter the food web structure and lead to major ecosystem level changes in an environment where consumers must make the most of the short productive period before the long winter sets in ${ }^{16}$.

The borealization of the Arctic phytoplankton phenology will also be accompanied by a longer period of regenerated production and subsurface $\mathrm{Chl} a$ maxima (SCM), particularly in low productivity waters (for example, in the Western Arctic Ocean; Fig. 5). Widespread $\mathrm{N}$ deficiency in surface waters drives the seasonal persistence of SCM layers and phytoplankton C biomass in several reg ions ${ }^{29,64,129,130}$. The contribution of these layers to NPP is possibly higher in the Arctic Ocean than in thermally stratified waters of the subtropical gyres due to a combination of extreme acclimation to low light and a shallow nitracline $\mathrm{e}^{31,131}$. Unsurprisingly, the deepening (related to the length of the growing season and the seasonal $\mathrm{N}$ consumption) and the steepness (associated to the intensity of the vertical stratification) of the nitracline determines the depth, biomass, productivity and assemblage composition of SCMs ${ }^{64,132,133}$. For the deepest SCMs in late summer, even shifts from autotrophic to heterotrophic communities have been revealed due to severe light limitation $^{132}$. In the context of current sea-ice loss, the potentially increased role of SCM layers on biogeochemical fluxes remain to be quantified directly, both regionally and at the pan-Arctic scale ${ }^{31,127}$.

\section{Arctic phytoplankton assemblage structure}

Since the beginning of the nineteenth century, known Arctic and subarctic phytoplankton species have increased dramatically from 115 (ref. ${ }^{134}$ ) to 1,874 (ref. ${ }^{135}$ ) in 2011 , and ultimately reaching 2,241 taxa in the latest updated pan-Arctic taxonomic inventory in 2017 (ref. ${ }^{136}$ ). Here, our goal is not to describe this expanded understanding of Arctic phytoplankton diversity but rather to delineate the ecological niches of phytoplankton ranging from bloom-forming to ultra-oligotrophic adapted species in the changing Arctic environment (Fig. 6).

The prevailing view of Arctic Ocean phytoplankton assemblages is usually based on large diatom blooms (centric or pennate forms) in nutrient-rich waters supporting a cascade of higher trophic levels. What is less recognized is that some Arctic regions (for example, the Canada Basin) are as oligotrophic and unproductive as subtropical gyres ${ }^{12}$. The availability of $\mathrm{N}$ (mainly nitrate), which shapes the overall biogeography and regional trophic status of the Arctic, also drives large-scale shifts from diatom- to picoeukaryote (mostly flagellates)-dominated systems $\mathrm{s}^{29,64,137,138}$ (Fig. 6). This does not mean, however, that in less productive areas no diatom-dominated spring blooms can develop (except probably in perennial stratified Arctic 
a

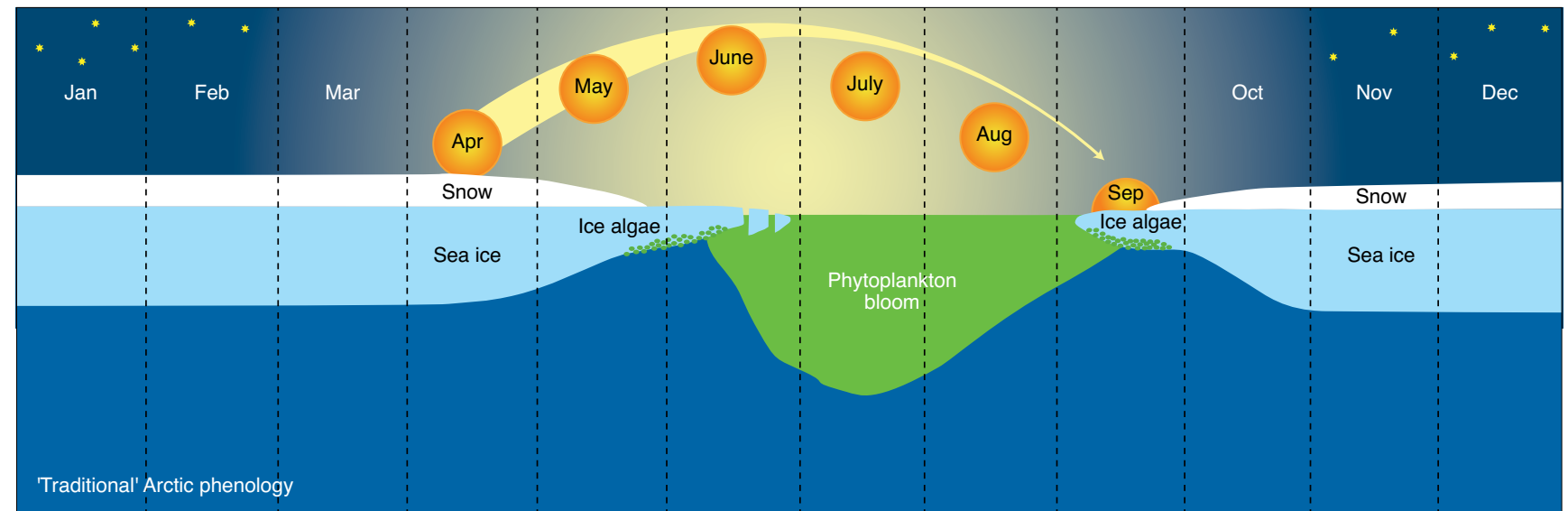

b

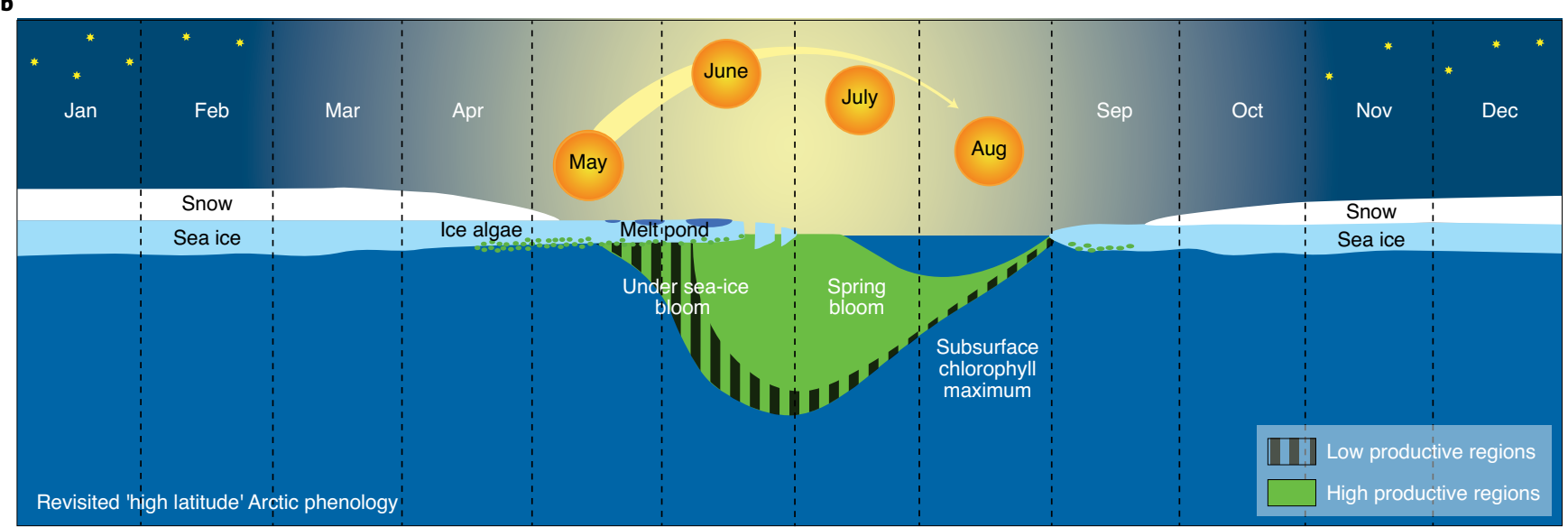

c

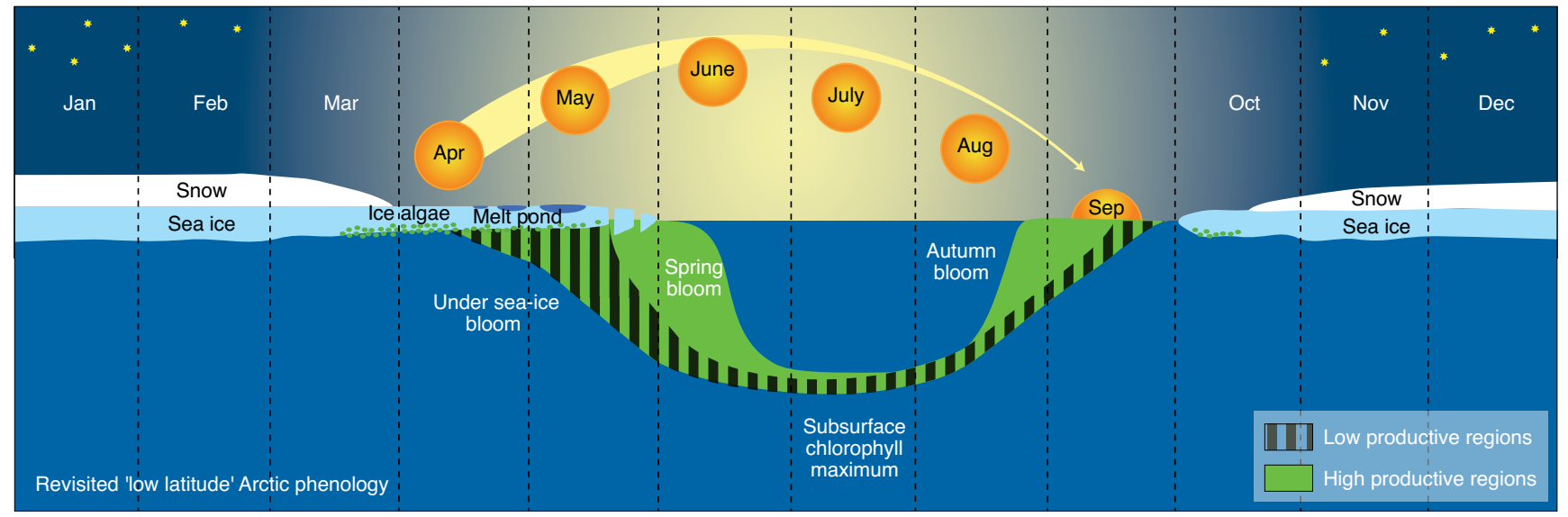

Fig. 5 | Changing Arctic sea-ice algae and phytoplankton phenology with the receding sea-ice cover. a, Traditional paradigm of seasonally ice-covered regions with the occurrence of a single annual phytoplankton bloom, and two blooms of sea-ice algae at the beginning and end of the productive season ${ }^{128,188}$. b,c. Potential changes in production and duration of the spring bloom due to early productive season and the occurrence of under-ice phytoplankton blooms at low (b) and high (c) Arctic latitudes $67,68,109,114,189$. In low (b) and high (c) Arctic latitudes, the presence and extent of sea-ice algae blooms could be affected by drastic changes in sea-ice dynamics ${ }^{103,107,190}$. With a longer ice-free season, an increase in the importance of SCMs (in both low and high Arctic latitudes) and secondary/autumn blooms (only in low Arctic latitudes, when wind-driven mixing is strong enough to erode the vertical stratification and that replenishes sun-lit surface waters in nutrients) in the annual NPP estimates is expected ${ }^{16}$. Figure adapted from Wassmann and Reigstad ${ }^{121}$ under a Creative Commons License (https://creativecommons.org/licenses/by/4.0/).

waters), but only that these will be less intense and likely shorter (Fig. 5). In warmer, stratified and oligotrophic Arctic surface waters with a longer sea-ice-free season, the picoeukaryotic systems (in particular, the endemic prasinophyte Micromonas polaris) ${ }^{139-141}$ are strongly suspected to rely on mixotrophy; that is, via osmotrophic and/or phagotrophic processes. Such an adaptive strategy of picoeukaryotes could increasingly be favoured over strictly phototrophic phytoplankton as sea ice continues to decline ${ }^{138}$. In addition, such a scenario could considerably increase the risk of the proliferation of potentially bloom-forming, harmful or toxic species currently 


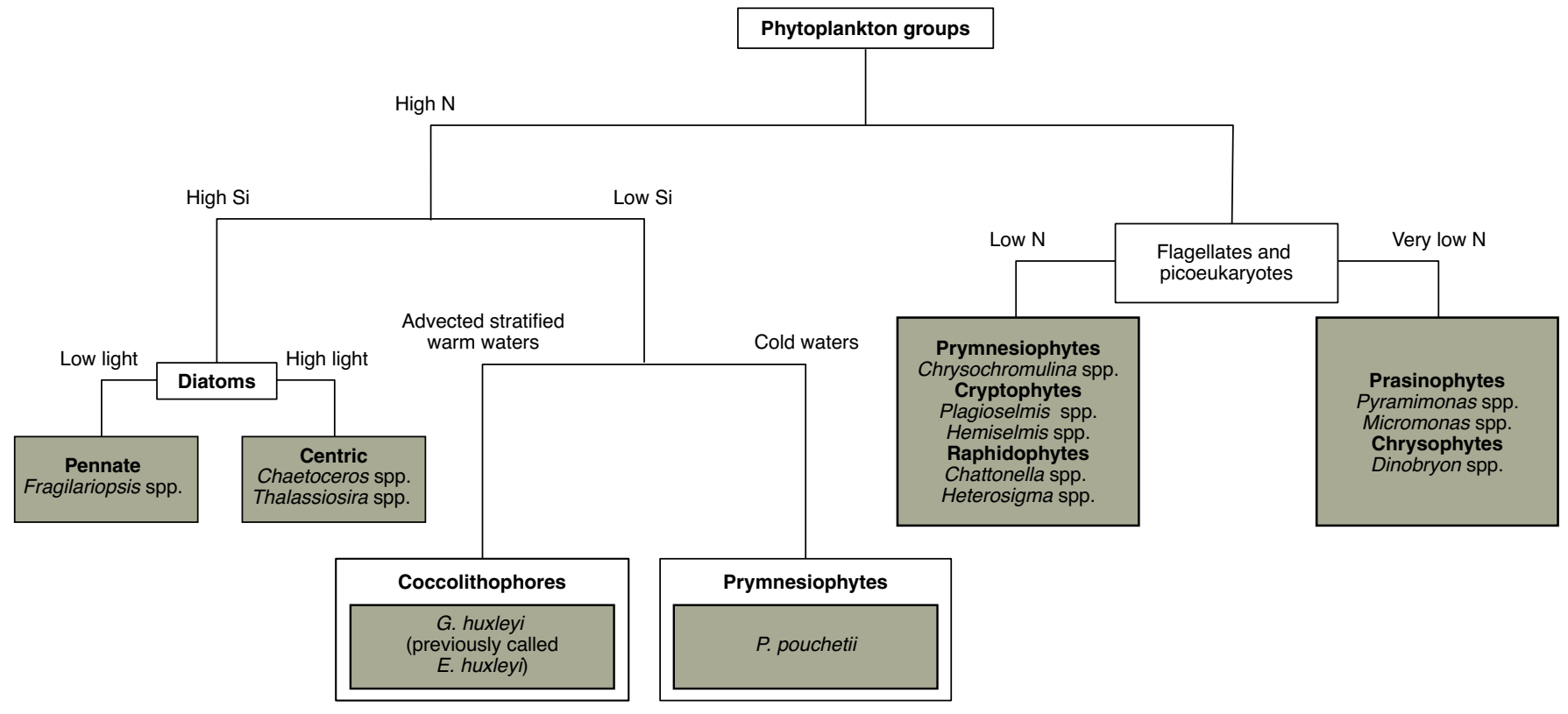

Fig. 6 | Major phytoplankton taxa and its environmental drivers in the Arctic Ocean. The schematic diagram delineates the main Arctic phytoplankton taxa driven by specific environmental drivers (that is, nutrient status, light and mixing regime, and water temperature). $\mathrm{N}$ and $\mathrm{Si}$ indicate nitrogen and silicate availability, respectively. Warm/stratified versus cold waters is related to hydrographic properties of the water masses. The different branches separate the phytoplankton taxa: the shift from diatom- to flagellates-based system (that is, high to low $\mathrm{N}$ ) ${ }^{29,64,137,191}$, the intra-specific taxa shift from pennate to centric diatoms (that is, low to high light) ${ }^{107,146,147,192,193}$, the shift from diatoms to (1) colonial prymnesiophytes, namely P. pouchetii (that is, high-to-low Si, cold waters), and to (2) coccolithophores (that is, high-to-low Si, advected warm/stratified waters) ${ }^{28,40,108,150,194}$, and the changes in phytoplankton taxa in the flagellates and picoeukaryotes ${ }^{64,138,142}$. Note the species E. huxleyi have recently reassigned based on genomic analyses to the coccolithophorid G. huxleyi ${ }^{39}$.

present in the Arctic Ocean (for example: diatom, Pseudo-nitzschia; dinoflagellate, Alexandrium, Dinophysis and Karlodinium; and prymnesiophyte, Chrysochromulina spp. $)^{135,140,142-144}$, potentially affecting already fragile marine Arctic ecosytems ${ }^{145}$.

Diatoms, which commonly exhibit seasonal succession from pennate to centric species due to different light requirements ${ }^{146,147}$, are not the only bloom-forming taxa observed in the Arctic Ocean (Fig. 6). Two other types of phytoplankton blooms have been reported, dominated either by the prymnesiophyte Phaeocystis pouchetii or by coccolithophores (Fig. 6). P. pouchetii blooms have long been observed in the Eurasian Arctic ${ }^{148,149}$ but are relatively recent phenomena in Labrador fjords $s^{150,151}$, Baffin Bay ${ }^{108}$ and under sea ice ${ }^{109}$. Silicate limitation can likely explain more favourable growth conditions for $P$. pouchetii compared to diatoms ${ }^{108,152}$ and the co-occurrence or succession between diatoms and $P$. pouchetii ${ }^{153}$. Since the early 1990 s, silicate concentration has decreased by $20 \%$ (and nitrate by $7 \%$ ) in inflowing Atlantic waters due to natural multi-decadal changes in surface circulation and decreased depth of winter convection at lower latitudes ${ }^{42,154,155}$. Thus, as Atlantic Ocean silicate supplies continue to decline, $P$. pouchetii blooms may become more common in eastern Baffin Bay waters and perhaps at higher latitudes of the Eurasian Arctic sector, while diatom-dominated blooms will become less frequent. Coccolithophores, considered as new intruders to the Arctic Ocean and sentinel taxa in temperate waters, have already been discussed in detail in the previous subsection titled 'Advection at the Arctic gateways'.

Understanding overwintering strategies (including mixotrophy, dormancy and cyst or spore formation), dark survival and recovery among phytoplankton taxa are also urgent matters to resolve, particularly with ongoing environmental changes (for example, increasing water temperature and sea-ice loss). Cyst and spore production has been reported in polar phytoplankton taxa but remains limited to a few diatom and dinoflagellate species ${ }^{147,156}$. Arctic diatoms have also been reported to survive long periods of darkness and resume rapid growth as soon as light becomes available due to their ability to downregulate their metabolism and to maintain the main components of their photosynthetic machinery (PSII, pigments and Rubisco) at low light and temperature ${ }^{157,158}$. On the other hand, mixotrophy seems to be a widespread strategy among dinoflagellates and other photosynthetic flagellate taxa, keeping them active throughout the polar night ${ }^{139,159-161}$. With higher temperatures in the future, photosynthetic flagellate taxa that rely on heterotrophy could have an advantage over diatoms that exhaust stored metabolic resources more quickly ${ }^{140,162}$ during the polar night ${ }^{140}$. The taxon-specific survival traits between diatoms and flagellates could shape their geographical distribution in high latitude regions and thus the community structure during the preconditioning period of the spring bloom, thereby impacting both the phenology and magnitude of the bloom ${ }^{163}$.

\section{Future Arctic Ocean and open questions}

It is evident that the shift of the Arctic Ocean to a new atmospheric, cryospheric and oceanic state is resulting in profound and widespread changes in phytoplankton dynamics. Despite the many examples of the effects of this new Arctic 'biogeochemical landscape' on phytoplankton productivity, phenology and assemblage composition, foreseeing the consequences of intensifying climate change remains difficult. Model predictions can be particularly relevant to identify key climate change-mediated multi-stressors ${ }^{164,165}$ and to better portray the future Arctic Ocean ${ }^{166,167}$. However, the taxonomic complexity of phytoplankton assemblages within diverse Arctic marine ecosystems remains difficult to model and parameterize correctly due to multiple little-known factors affecting growth $^{168}$. For example, no model has been able to reproduce the observed changes in phytoplankton phenology (for example, the occurrence of under-ice and secondary/autumn blooms) due to unique temperature- and light-dependent growth as well as metabolism of Arctic phytoplankton communities ${ }^{116,131,169,170}$. This is best 
exemplified by recent observations that have challenged the perception of the polar night, which has been shown to be a more active period for marine ecosystems and intense biogeochemical fluxes than previously recognized ${ }^{158,171-173}$. Almost all recent winter expeditions have revealed unexpected scientific breakthroughs ${ }^{172,173}$, and much remains to be done to document the key role of the polar night as a true continuum between the autumn and spring, and to better integrate it into the Arctic biogeochemical cycles.

Through the mosaic of environmental drivers influenced by climate change presented here, it is difficult to highlight particular 'sentinel' regions to be monitored in the near future: the interior shelves are mostly shaped by the land-ocean continuum, inflow and outflow shelves by advection, and the central Arctic by likely irreversible sea-ice loss. With the continued shrinking of the Arctic marine biome, however, multiple questions will need answers to better anticipate changes in the biogeochemical cycles of the central Arctic and predict its future. It is not yet possible to make definitive predictions about whether the central Arctic will become a new oasis or desert within the Arctic marine biome. However, we suspect that the shelf break, acting as a 'green belt', could effectively supply inorganic and organic matter to the strongly stratified, but soon-to-be sea-ice-free in summer, central Arctic Ocean ${ }^{64,174}$. The key question is whether or not the disappearance of the summer sea-ice barrier will enhance atmospheric forcing and increase the efficiency of mixing on $\mathrm{C}$ cycling and nutrient exchanges.

As for the Arctic gateways, the importance of Pacific and Atlantic inflows that fundamentally shape Arctic biogeochemical cycles highlight the strong connectivity of the Arctic Ocean to the global ocean. In this Review, we mainly focused on the importance of potential changes in inflows from subarctic latitudes that carry heat, nutrients and planktonic organisms towards the Arctic Ocean. The reverse, also important but not addressed here, is the role of a changing Arctic Ocean on subarctic latitudes and the global circulation and climate. The initiation of industrial-era decline in subarctic Atlantic Ocean primary productivity, for example, seems to coincide with the onset of Arctic Ocean surface warming ${ }^{175,176}$. More importantly, the increasing long-term influx of freshwater into northeastern subarctic Atlantic surface waters may be implicated in driving the industrial-era Atlantic Meridional Overturning Circulation (AMOC) decline and contributed to this primary productivity decline over the late nineteenth and twentieth centuries $^{176-180}$. Continued weakening of the AMOC, as projected for the twenty-first century ${ }^{181,182}$, may therefore result in further productivity declines, with important ramifications for future atmospheric $\mathrm{C}$ drawdown ${ }^{183}$ and northern Atlantic fisheries ${ }^{184}$ in the subarctic Atlantic Ocean ${ }^{176}$.

Received: 20 December 2018; Accepted: 7 August 2020; Published online: 25 September 2020

\section{References}

1. AMAP. Snow, Water, Ice and Permafrost in the Arctic (SWIPA) 2017 (AMAP, 2017)

2. Notz, D. \& Stroeve, J. Observed Arctic sea-ice loss directly follows anthropogenic $\mathrm{CO}_{2}$ emission. Science 354, 747-750 (2016).

3. Haine, T. W. N. et al. Arctic freshwater export: status, mechanisms, and prospects. Glob. Planet. Change 125, 13-35 (2015).

4. Aagaard, K. \& Carmack, E. C. The role of sea ice and other fresh water in the Arctic circulation. J. Geophys. Res. 94, 14485-14498 (1989).

5. Aagaard, K., Coachman, L. K. \& Carmack, E. On the halocline of the Arctic Ocean. Deep Sea Res. Pt A 28, 529-545 (1981).

6. Polyakov, I. V. et al. Greater role for Atlantic inflows on sea-ice loss in the Eurasian Basin of the Arctic Ocean. Science 356, 285-291 (2017).

7. Aagaard, K. \& Coachman, L. K. Toward an ice-free Arctic ocean. Eos Trans. Amer. Geophys. Union 56, 484-486 (1975).

8. Kwok, R. Arctic sea ice thickness, volume, and multiyear ice coverage: losses and coupled variability (1958-2018). Environ. Res. Lett. 13, 105005 (2018).
9. Post, E. et al. Ecological consequences of sea-ice decline. Science 341, 519-524 (2013).

10. Post, E. et al. Ecological dynamics across the Arctic associated with recent climate change. Science 325, 1355-1358 (2009).

11. Gregory, A. C. et al. Marine viral macro- and micro-diversity from pole to pole. Cell 177, 1109-1123 (2019).

12. Arrigo, K. R., van Dijken, G. \& Pabi, S. Impact of a shrinking Arctic ice cover on marine primary production. Geophys. Res. Lett. 35, L19603 (2008)

13. Kahru, M., Lee, Z.-P., Mitchell, B. G. \& Nevison, C. D. Effects of sea ice cover on satellite-detected primary production in the Arctic ocean. Biol. Lett. 12, 20160223 (2016).

14. Bélanger, S., Babin, M. \& Tremblay, J.-É. Increasing cloudiness in Arctic damps the increase in phytoplankton primary production due to sea ice receding. Biogeosciences 10, 4087-4101 (2013).

15. Kahru, M., Brotas, V., Manzano-Sarabio, M. \& Mitchell, B. G. Are phytoplankton blooms occurring earlier in the Arctic? Glob. Change Biol. 17, 1733-1739 (2010).

16. Ardyna, M. et al. Recent Arctic Ocean sea-ice loss triggers novel fall phytoplankton blooms. Geophys. Res. Lett. 41, 6207-6212 (2014).

17. Arrigo, K. R. \& van Dijken, G. L. Continued increases in Arctic Ocean primary production. Prog. Oceanogr. 136, 60-70 (2015).

18. Lewis, K. M., van Dijken, G. \& Arrigo, K. R. Changes in phytoplankton concentration, not sea ice, now drive increased Arctic Ocean primary production. Science 369, 198-202 (2020).

19. Olson, M. B. \& Strom, S. L. Phytoplankton growth, microzooplankton herbivory and community structure in the southeast Bering Sea: insight into the formation and temporal persistence of an Emiliania huxleyi bloom. Deep Sea Res. Pt. 2 49, 5969-5990 (2002).

20. Sherr, E. B., Sherr, B. F. \& Ross, C. Microzooplankton grazing impact in the Bering Sea during spring sea ice conditions. Deep Sea Res. Pt. 2 94, 57-67 (2013).

21. Forest, A. et al. Biogenic carbon flows through the planktonic food web of the Amundsen Gulf (Arctic Ocean): a synthesis of field measurements and inverse modeling analyses. Prog. Oceanogr. 91, 410-436 (2011).

22. Franzè, G. \& Lavrentyev, P. J. Microbial food web structure and dynamics across a natural temperature gradient in a productive polar shelf system. Mar. Ecol. Prog. Ser. 569, 89-102 (2017).

23. Menden-Deuer, S., Lawrence, C. \& Franzè, G. Herbivorous protist growth and grazing rates at in situ and artificially elevated temperatures during an Arctic phytoplankton spring bloom. PeerJ 6, e5264 (2018).

24. Carmack, E. C. \& Wassmann, P. Food webs and physical-biological coupling on pan-Arctic shelves: unifying concepts and comprehensive perspectives. Prog. Oceanogr. 71, 446-477 (2006).

25. Harrison, W. G. \& Cota, G. F. Primary production in polar waters: relation to nutrient availability. Polar Res. 10, 87-104 (1991).

26. Sakshaug, E. in The Organic Carbon Cycle in the Arctic Ocean (eds Stein, R. \& MacDonald, R. W.) 57-81 (Springer, 2004).

27. Michel, C., Nielsen, T. G., Nozais, C. \& Gosselin, M. Significance of sedimentation and grazing by ice micro- and meiofauna for carbon cycling in annual sea ice (northern Baffin Bay). Aquat. Microb. Ecol. 30, $57-68$ (2002).

28. Krause, J. W. et al. Biogenic silica production and diatom dynamics in the Svalbard region during spring. Biogeosciences 15, 6503-6517 (2018).

29. Ardyna, M., Gosselin, M., Michel, C., Poulin, M. \& Tremblay, J.-É. Environmental forcing of phytoplankton community structure and function in the Canadian High Arctic: contrasting oligotrophic and eutrophic regions. Mar. Ecol. Prog. Ser. 442, 37-57 (2011).

30. Taylor, R. L. et al. Colimitation by light, nitrate, and iron in the Beaufort Sea in late summer. J. Geophys. Res. 118, 3260-3277 (2013).

31. Tremblay, J.-É. et al. Global and regional drivers of nutrient supply, primary production and $\mathrm{CO}_{2}$ drawdown in the changing Arctic Ocean. Prog. Oceanogr. 139, 171-196 (2015).

32. Tremblay, J.-E. \& Gagnon, J. in Influence of Climate Change on the Changing Arctic and Sub-Arctic Conditions (eds J. C. J. Nihoul \& A. G. Kostianoy) 73-93 (Springer, 2009).

33. Michel, C. et al. Arctic Ocean outflow shelves in the changing Arctic: a review and perspectives. Prog. Oceanogr. 139, 66-88 (2015).

34. Bourgault, D. et al. Turbulent nitrate fluxes in the Amundsen Gulf during ice-covered conditions. Geophys. Res. Lett. 38, L15602 (2011).

35. Randelhoff, A., Fer, I., Sundfjord, A., Tremblay, J.-É. \& Reigstad, M. Vertical fluxes of nitrate in the seasonal nitracline of the Atlantic sector of the Arctic Ocean. J. Geophys. Res. Oceans 121, 5282-5295 (2016).

36. Toole, J. M. et al. Influences of the ocean surface mixed layer and thermohaline stratification on Arctic Sea ice in the central Canada Basin. J. Geophys. Res. Oceans 115, C10018 (2010).

37. Lind, S., Ingvaldsen, R. B. \& Furevik, T. Arctic warming hotspot in the northern Barents Sea linked to declining sea-ice import. Nat. Clim. Change 8, 634-639 (2018). 
38. Mioduszewski, J., Vavrus, S. \& Wang, M. Diminishing Arctic sea ice promotes stronger surface winds. J. Climate 31, 8101-8119 (2018).

39. Bendif, E. M. et al. Repeated species radiations in the recent evolution of the key marine phytoplankton lineage Gephyrocapsa. Nat. Commun. 10, 4234 (2019).

40. Oziel, L. et al. Faster Atlantic currents drive poleward expansion of temperate marine species in the Arctic Ocean. Nat. Commun. 11, 1705 (2020).

41. Neukermans, G., Oziel, L. \& Babin, M. Increased intrusion of warming Atlantic water leads to rapid expansion of temperate phytoplankton in the Arctic. Glob. Change Biol. 24, 2545-2553 (2018).

42. Oziel, L. et al. Role for Atlantic inflows and sea ice loss on shifting phytoplankton blooms in the Barents Sea. J. Geophys. Res. 122, 5121-5139 (2017)

43. Paulsen, M. L. et al. Synechococcus in the Atlantic gateway to the Arctic Ocean. Front. Mar. Sci. 3, 191 (2016).

44. Winter, A., Henderiks, J., Beaufort, L., Rickaby, R. E. M. \& Brown, C. W. Poleward expansion of the coccolithophore Emiliania huxleyi. J. Plankton Res. 36, 316-325 (2014).

45. Wassmann, P. et al. The contiguous domains of Arctic Ocean advection: trails of life and death. Prog. Oceanogr. 139, 42-65 (2015).

46. Kortsch, S., Primicerio, R., Fossheim, M., Dolgov, A. V. \& Aschan, M. Climate change alters the structure of arctic marine food webs due to poleward shifts of boreal generalists. Proc. Royal Soc. B 282, 20151546 (2015)

47. Frainer, A. et al. Climate-driven changes in functional biogeography of Arctic marine fish communities. Proc. Natl Acad. Sci. USA 114, 12202-12207 (2017)

48. Fossheim, M. et al. Recent warming leads to a rapid borealization of fish communities in the Arctic. Nat. Clim. Change 5, 673-677 (2015).

49. Beaugrand, G. et al. Prediction of unprecedented biological shifts in the global ocean. Nat. Clim. Change 9, 237-243 (2019).

50. Carmack, E. C. et al. Freshwater and its role in the Arctic marine system: sources, disposition, storage, export, and physical and biogeochemical consequences in the Arctic and global oceans. J. Geophys. Res. Biogeosci. 121, 675-717 (2016).

51. Marchese, C. et al. Changes in phytoplankton bloom phenology over the North Water (NOW) polynya: a response to changing environmental conditions. Polar Biol. 40, 1721-1737 (2017).

52. Mayot, N. et al. Springtime export of Arctic sea ice influences phytoplankton production in the Greenland Sea. J. Geophys. Res. Oceans 125, e2019JC015799 (2020).

53. Carmack, E. C. The alpha/beta ocean distinction: a perspective on freshwater fluxes, convection, nutrients and productivity in high-latitude seas. Deep Sea Res. Pt. 2 54, 2578-2598 (2007).

54. Blais, M. et al. Contrasting interannual changes in phytoplankton productivity and community structure in the coastal Canadian Arctic Ocean. Limnol. Oceanogr. 62, 2480-2497 (2017).

55. Meire, L. et al. High export of dissolved silica from the Greenland Ice Sheet. Geophys. Res. Lett. 43, 9173-9182 (2016).

56. Hawkings, J. R. et al. Ice sheets as a significant source of highly reactive nanoparticulate iron to the oceans. Nat. Commun. 5, 3929 (2014).

57. Hawkings, J. et al. The Greenland Ice Sheet as a hot spot of phosphorus weathering and export in the Arctic. Glob. Biogeochem. Cycle 30, 191-210 (2016).

58. Arrigo, K. R. et al. Melting glaciers stimulate large summer phytoplankton blooms in southwest Greenland waters. Geophys. Res. Lett. 44 6278-6285 (2017).

59. Meire, L. et al. Marine-terminating glaciers sustain high productivity in Greenland fjords. Glob. Change Biol. 23, 5344-5357 (2017).

60. Boone, W. et al. Coastal freshening prevents fjord bottom water renewal in northeast Greenland: a mooring study from 2003 to 2015. Geophys. Res. Lett. 45, 2726-2733 (2018).

61. Le Fouest, V. et al. Modeling plankton ecosystem functioning and nitrogen fluxes in the oligotrophic waters of the Beaufort Sea, Arctic Ocean: a focus on light-driven processes. Biogeosciences 10, 4785-4800 (2013).

62. Le Fouest, V., Manizza, M., Tremblay, B. \& Babin, M. Modelling the impact of riverine DON removal by marine bacterioplankton on primary production in the Arctic Ocean. Biogeosciences 12, 3385-3402 (2015).

63. Tremblay, J.-É. et al. Impact of river discharge, upwelling and vertical mixing on the nutrient loading and productivity of the Canadian Beaufort Shelf. Biogeosciences 11, 4853-4868 (2014).

64. Ardyna, M. et al. Shelf-basin gradients shape ecological phytoplankton niches and community composition in the coastal Arctic Ocean (Beaufort Sea). Limnol. Oceanogr. 62, 2113-2132 (2017).

65. Fichot, C. G. et al. Pan-Arctic distributions of continental runoff in the Arctic Ocean. Sci. Rep. 3, 1053 (2013).

66. Matsuoka, A. et al. Pan-Arctic optical characteristics of colored dissolved organic matter: tracing dissolved organic carbon in changing Arctic waters using satellite ocean color data. Remote Sens. Environ. 200, 89-101 (2017)
67. Arrigo, K. R. et al. Phytoplankton blooms beneath the sea ice in the Chukchi Sea. Deep Sea Res. Pt. 2 105, 1-16 (2014).

68. Arrigo, K. R. et al. Massive phytoplankton blooms under Arctic sea ice. Science 336, 1408 (2012).

69. Kelly, R. et al. Recent burning of boreal forests exceeds fire regime limits of the past 10,000 years. Proc. Natl Acad. Sci. USA 110, 13055-13060 (2013).

70. French, N. H. F. et al. Fire in Arctic tundra of Alaska: past fire activity, future fire potential, and significance for land management and ecology. Int. J. Wildland Fire 24, 1045-1061 (2015).

71. Masrur, A., Petrov, A. N. \& DeGroote, J. Circumpolar spatio-temporal patterns and contributing climatic factors of wildfire activity in the Arctic tundra from 2001-2015. Environ. Res. Lett. 13, 014019 (2018).

72. Evangeliou, N. et al. Open fires in Greenland in summer 2017: transport, deposition and radiative effects of $\mathrm{BC}, \mathrm{OC}$ and $\mathrm{BrC}$ emissions. Atmos. Chem. Phys. 19, 1393-1411 (2019).

73. Lutsch, E. et al. Unprecedented atmospheric ammonia concentrations detected in the high Arctic from the 2017 Canadian wildfires. J. Geophys. Res. Atmos. 124, 8178-8202 (2019).

74. Skiles, S. M., Flanner, M., Cook, J. M., Dumont, M. \& Painter, T. H. Radiative forcing by light-absorbing particles in snow. Nat. Clim. Change $\mathbf{8}$ 964-971 (2018).

75. Light, B., Eicken, H., Maykut, G. A. \& Grenfell, T. C. The effect of included participates on the spectral albedo of sea ice. J. Geophys. Res. Oceans $\mathbf{1 0 3}$ 27739-27752 (1998)

76. Holland, M. M., Bailey, D. A., Briegleb, B. P., Light, B. \& Hunke, E. Improved sea ice shortwave radiation physics in CCSM4: the impact of melt ponds and aerosols on Arctic sea ice. J. Climate 25, 1413-1430 (2011).

77. Marks, A. A., Lamare, M. L. \& King, M. D. Optical properties of sea ice doped with black carbon - an experimental and radiative-transfer modelling comparison. Cryosphere 11, 2867-2881 (2017).

78. Dentener, F. et al. Nitrogen and sulfur deposition on regional and global scales: a multimodel evaluation. Glob. Biogeochem. Cycle 20, GB4003 (2006).

79. Mahowald, N. et al. Global distribution of atmospheric phosphorus sources, concentrations and deposition rates, and anthropogenic impacts. Glob. Biogeochem. Cycle 22, GB4026 (2008).

80. Torres-Valdés, S., Tsubouchi, T., Davey, E., Yashayaev, I. \& Bacon, S. Relevance of dissolved organic nutrients for the Arctic Ocean nutrient budget. Geophys. Res. Lett. 43, 6418-6426 (2016).

81. AMAP Assessment 2018: Arctic Ocean Acidification (AMAP, 2018).

82. Yamamoto-Kawai, M., McLaughlin, F. A., Carmack, E. C., Nishino, S. \& Shimada, K. Aragonite undersaturation in the Arctic Ocean: effects of ocean acidification and sea ice melt. Science 326, 1098-1100 (2009).

83. Qi, D. et al. Increase in acidifying water in the western Arctic Ocean. Nat Clim. Change 7, 195-199 (2017).

84. Terhaar, J., Kwiatkowski, L. \& Bopp, L. Emergent constraint on Arctic Ocean acidification in the twenty-first century. Nature 582, 379-383 (2020).

85. Hoppe, C. J. M. et al. Resistance of Arctic phytoplankton to ocean acidification and enhanced irradiance. Polar Biol. 41, 399-413 (2018).

86. Hoppe, C. J. M., Schuback, N., Semeniuk, D. M., Maldonado, M. T. \& Rost, B. Functional redundancy facilitates resilience of subarctic phytoplankton assemblages toward ocean acidification and high irradiance. Front. Mar. Sci. 4, 229 (2017).

87. Hoppe, C. J. M., Wolf, K. K. E., Schuback, N., Tortell, P. D. \& Rost, B. Compensation of ocean acidification effects in Arctic phytoplankton assemblages. Nat. Clim. Change 8, 529-533 (2018).

88. Hussherr, R. et al. Impact of ocean acidification on Arctic phytoplankton blooms and dimethyl sulfide concentration under simulated ice-free and under-ice conditions. Biogeosciences 14, 2407-2427 (2017).

89. White, E., Hoppe, C. J. M. \& Rost, B. The Arctic picoeukaryote Micromonas pusilla benefits from ocean acidification under constant and dynamic light. Biogeosciences 17, 635-647 (2020).

90. Yoshimura, T. et al. Impacts of elevated $\mathrm{CO}_{2}$ on particulate and dissolved organic matter production: microcosm experiments using iron-deficient plankton communities in open subarctic waters. J. Oceanogr. 69, 601-618 (2013).

91. Thoisen, C., Riisgaard, K., Lundholm, N., Nielsen, T. G. \& Hansen, P. J. Effect of acidification on an Arctic phytoplankton community from Disko Bay, West Greenland. Mar. Ecol. Prog. Ser. 520, 21-34 (2015).

92. Coello-Camba, A., Agustí, S., Holding, J., Arrieta, J. M. \& Duarte, C. M. Interactive effect of temperature and $\mathrm{CO}_{2}$ increase in Arctic phytoplankton. Front. Mar. Sci. 1, 49 (2014)

93. Perovich, D. K. \& Polashenski, C. Albedo evolution of seasonal Arctic sea ice. Geophys. Res. Lett. 39, L08501 (2012).

94. Perovich, D. K. The Optical Properties of Sea Ice (Office of Naval Research, 1996)

95. Hill, V. J., Cota, G. \& Stockwell, D. Spring and summer phytoplankton communities in the Chukchi and Eastern Beaufort Seas. Deep Sea Res. Pt 2 52, 3369-3385 (2005) 
96. Perrette, M., Yool, A., Quartly, G. D. \& Popova, E. E. Near-ubiquity of ice-edge blooms in the Arctic. Biogeosciences 7, 515-524 (2011).

97. Janout, M. A. et al. Sea-ice retreat controls timing of summer plankton blooms in the Eastern Arctic Ocean. Geophys. Res. Lett. 12, 12493-12501 (2016)

98. Sakshaug, E. Biomass and productivity distributions and their variability in the Barents Sea. ICES J. Mar. Sci. 54, 341-350 (1997).

99. Subba Rao, D. V. \& Platt, T. Primary production of arctic waters. Polar Biol. 3, 191-201 (1984).

100. Pabi, S., van Dijken, G. L. \& Arrigo, K. R. Primary production in the Arctic Ocean, 1998-2006. J. Geophys. Res. 113, C08005 (2008).

101. Arrigo, K. R. \& van Dijken, G. L. Secular trends in Arctic Ocean net primary production. J. Geophys. Res. 116, C09011 (2011).

102. Fortier, M., Fortier, L., Michel, C. \& Legendre, L. Climatic and biological forcing of the vertical flux of biogenic particles under seasonal Arctic sea ice. Mar. Ecol. Prog. Ser. 225, 1-16 (2002)

103. Mundy, C. J. et al. Role of environmental factors on phytoplankton bloom initiation under landfast sea ice in Resolute Passage, Canada. Mar. Ecol. Prog. Ser. 497, 39-49 (2014).

104. Duerksen, S. W. et al. Large, omega-3 rich, pelagic diatoms under Arctic Sea ice: sources and Implications for food webs. PLoS ONE 9, e114070 (2014)

105. Galindo, V. et al. Contrasted sensitivity of DMSP production to high light exposure in two Arctic under-ice blooms. J. Exp. Mar. Biol. Ecol. 475, 38-48 (2016).

106. Galindo, V. et al. Under-ice microbial dimethylsulfoniopropionate metabolism during the melt period in the Canadian Arctic Archipelago. Mar. Ecol. Prog. Ser. 524, 39-53 (2015).

107. Galindo, V. et al. Biological and physical processes influencing sea ice, under-ice algae, and dimethylsulfoniopropionate during spring in the Canadian Arctic Archipelago. J. Geophys. Res. Oceans 119, 3746-3766 (2014).

108. Ardyna, M. et al. Ecological drivers controlling spring phytoplankton blooms in the Arctic Ocean. Elem. Sci. Anth. 8, 30 (2020).

109. Assmy, P. et al. Leads in Arctic pack ice enable early phytoplankton blooms below snow-covered sea ice. Sci. Rep. 7, 40850 (2017)

110. Mayot, N. et al. Assessing phytoplankton activities in the seasonal ice zone of the Greenland Sea over an annual cycle. J. Geophys. Res. Oceans 123, 8004-8025 (2018).

111. Strass, V. H. \& Nöthig, E.-M. Seasonal shifts in ice edge phytoplankton blooms in the Barents Sea related to the water column stability. Polar Biol. 16, 409-422 (1996).

112. Pavlov, A. K. et al. Altered inherent optical properties and estimates of the underwater light field during an Arctic under-ice bloom of Phaeocystis pouchetii. J. Geophys. Res. Oceans 122, 4939-4961 (2017).

113. Lalande, C. et al. Variability in under-ice export fluxes of biogenic matter in the Arctic Ocean. Glob. Biogeochem. Cycle 28, 571-583 (2014)

114. Yager, P. L. et al. Dynamic bacterial and viral response to an algal bloom at subzero temperatures. Limnol. Oceanogr. 46, 790-801 (2001).

115. Hill, V. J., Light, B., Steele, M. \& Zimmerman, R. C. Light availability and phytoplankton growth beneath Arctic sea ice: integrating observations and modeling. J. Geophys. Res. Oceans 123, 3651-3667 (2018).

116. Lewis, K. M. et al. Photoacclimation of Arctic Ocean phytoplankton to shifting light and nutrient limitation. Limnol. Oceanogr. 64, 284-301 (2019).

117. Grebmeier, J. M. Shifting patterns of life in the Pacific Arctic and sub-Arctic seas. Annu. Rev. Mar. Sci. 4, 63-78 (2012).

118. Grebmeier, J. M., Moore, S. E., Overland, J. E., Frey, K. E. \& Gradinger, R. Biological response to recent Pacific Arctic sea ice retreats. Eos Trans. Amer Geophys. Union 91, 161-162 (2010).

119. Tamelander, T., Kivimäe, C., Bellerby, R. G. J., Renaud, P. E. \& Kristiansen, $\mathrm{S}$. Base-line variations in stable isotope values in an Arctic marine ecosystem: effects of carbon and nitrogen uptake by phytoplankton. Hydrobiologia 630, 63-73 (2009).

120. Degen, R. et al. Patterns and drivers of megabenthic secondary production on the Barents Sea shelf. Mar. Ecol. Prog. Ser. 546, 1-16 (2016).

121. Wassmann, P. \& Reigstad, M. Future Arctic Ocean seasonal ice zones and implications for pelagic-benthic coupling. Oceanography 24, 220-231 (2011).

122. Fujiwara, A. et al. Changes in phytoplankton community structure during wind-induced fall bloom on the central Chukchi shelf. Polar Biol. 41, 1279-1295 (2018).

123. Uchimiya, M. et al. Coupled response of bacterial production to a wind-induced fall phytoplankton bloom and sediment resuspension in the Chukchi Sea Shelf, Western Arctic Ocean. Front. Mar. Sci. 3, 231 (2016).

124. Goñi, M. A. et al. Particulate organic matter distributions in surface waters of the Pacific Arctic shelf during the late summer and fall season. Mar. Chem. 211, 75-93 (2019).

125. Juranek, L., Takahashi, T., Mathis, J. \& Pickart, R. Significant biologically mediated $\mathrm{CO}_{2}$ uptake in the Pacific Arctic during the late open water season. J. Geophys. Res. Oceans 124, 821-843 (2019).
126. Not, F. et al. Late summer community composition and abundance of photosynthetic picoeukaryotes in Norwegian and Barents Seas. Limnol. Oceanogr. 50, 1677-1686 (2005).

127. Ardyna, M. et al. Parameterization of vertical chlorophyll $a$ in the Arctic Ocean: impact of the subsurface chlorophyll maximum on regional, seasonal, and annual primary production estimates. Biogeosciences 10, 4383-4404 (2013).

128. Wassmann, P., Peinert, R. \& Smetacek, V. Patterns of production and sedimentation in the boreal and polar Northeast Atlantic. Polar Res. 10, 209-228 (1991).

129. Martin, J. et al. Prevalence, structure and properties of subsurface chlorophyll maxima in Canadian Arctic waters. Mar. Ecol. Prog. Ser. 412, 69-84 (2010).

130. Coupel, P. et al. The impact of freshening on phytoplankton production in the Pacific Arctic Ocean. Prog. Oceanogr. 131, 113-125 (2015).

131. Huot, Y., Babin, M. \& Bruyant, F. Photosynthetic parameters in the Beaufort Sea in relation to the phytoplankton community structure. Biogeosciences 10, 3445-3454 (2013).

132. Monier, A. et al. Oceanographic structure drives the assembly processes of microbial eukaryotic communities. ISME J. 9, 990-1002 (2014).

133. McLaughlin, F. A. \& Carmack, E. C. Deepening of the nutricline and chlorophyll maximum in the Canada Basin interior. Geophys. Res. Lett. 37, L24602 (2010).

134. Gran, H. H. Das Plankton des norwegischen Nordmeeres (Fiskeridirektoratets havforskningsinstitutt, 1902).

135. Poulin, M. et al. The pan-Arctic biodiversity of marine pelagic and sea-ice unicellular eukaryotes: a first-attempt assessment. Mar. Biodiv. 41, 13-28 (2011).

136. Lovejoy, C., von Quillfeldt, C., Hopcroft, R. R., Poulin, M. \& Thaler, M. in State of the Arctic Marine Biodiversity Report (eds T Barry. et al.) 62-83 (Conservation of Arctic Flora and Fauna International Secretariat, 2017).

137. Tremblay, G. et al. Late summer phytoplankton distribution along a 3500 $\mathrm{km}$ transect in Canadian Arctic waters: strong numerical dominance by picoeukaryotes. Aquat. Microb. Ecol. 54, 55-70 (2009).

138. Berge, J. et al. Diel vertical migration of Arctic zooplankton during the polar night. Biol. Lett. 5, 69-72 (2009)

139. Lovejoy, C. et al. Distribution, phylogeny, and growth of cold-adapted picoprasinophytes in Arctic seas. J. Phycol. 43, 78-89 (2007).

140. Stoecker, D. K. \& Lavrentyev, P. J. Mixotrophic plankton in the polar seas: a pan-Arctic review. Front. Mar. Sci. 5, 292 (2018)

141. Balzano, S. et al. Diversity of cultured photosynthetic flagellates in the northeast Pacific and Arctic Oceans in summer. Biogeosciences $\mathbf{9}$, 4553-4571 (2012)

142. Joli, N. et al. Need for focus on microbial species following ice melt and changing freshwater regimes in a Janus Arctic Gateway. Sci. Rep. 8 9405 (2018).

143. Okolodkov, Y. B. The global distributional patterns of toxic, bloom dinoflagellates recorded from the Eurasian Arctic. Harmful Algae 4 351-369 (2005).

144. Brosnahan, M. L., Fischer, A. D., Lopez, C. B., Moore, S. K. \& Anderson, D. M. Cyst-forming dinoflagellates in a warming climate. Harmful Algae 91, 101728 (2020).

145. Lefebvre, K. A. et al. Prevalence of algal toxins in Alaskan marine mammals foraging in a changing arctic and subarctic environment. Harmful Algae 55, 13-24 (2016).

146. Lovejoy, C., Legendre, L., Martineau, M. J., Bacle, J. \& von Quillfeldt, C. H. Distribution of phytoplankton and other protists in the North Water. Deep Sea Res. Pt 2 49, 5027-5047 (2002).

147. Booth, B. C. et al. Dynamics of Chaetoceros socialis blooms in the North Water. Deep Sea Res. Pt 2 49, 5003-5025 (2002).

148. Schoemann, V., Becquevort, S., Stefels, J., Rousseau, V. \& Lancelot, C. Phaeocystis blooms in the global ocean and their controlling mechanisms: a review. J. Sea. Res. 53, 43-66 (2005).

149. Smith, W. O. et al. Importance of Phaeocystis blooms in the high-latitude ocean carbon cycle. Nature 352, 514-516 (1991).

150. Simo-Matchim, A. G., Gosselin, M., Poulin, M., Ardyna, M. \& Lessard, S. Summer and fall distribution of phytoplankton in relation to environmental variables in Labrador fjords, with special emphasis on Phaeocystis pouchetii. Mar. Ecol. Prog. Ser. 572, 19-42 (2017).

151. Crawford, D. W., Cefarelli, A. O., Wrohan, I. A., Wyatt, S. N. \& Varela, D. E. Spatial patterns in abundance, taxonomic composition and carbon biomass of nano- and microphytoplankton in Subarctic and Arctic Seas. Prog. Oceanogr. 162, 132-159 (2018)

152. Nöthig, E.-M. et al. Summertime plankton ecology in Fram Strait-a compilation of long- and short-term observations. Polar Res. 34, 23349 (2015).

153. Hodal, H., Falk-Petersen, S., Hop, H., Kristiansen, S. \& Reigstad, M. Spring bloom dynamics in Kongsfjorden, Svalbard: nutrients, phytoplankton, protozoans and primary production. Polar Biol. 35, 191-203 (2012). 
154. Hátún, H. et al. The subpolar gyre regulates silicate concentrations in the North Atlantic. Sci. Rep. 7, 14576 (2017).

155. Slagstad, D., Wassmann, P. F. J. \& Ellingsen, I. Physical constrains and productivity in the future Arctic Ocean. Front. Mar. Sci. 2, 85 (2015).

156. Hegseth, E. N. et al. in The Ecosystem of Kongsfiorden, Svalbard (eds Hop, H. \& Wiencke, C.) 173-227 (Springer International Publishing, 2019).

157. Lacour, T. et al. Decoupling light harvesting, electron transport and carbon fixation during prolonged darkness supports rapid recovery upon re-illumination in the Arctic diatom Chaetoceros neogracilis. Polar Biol. http://doi.org/d6rs (2019).

158. Kvernvik, A. C. et al. Fast reactivation of photosynthesis in arctic phytoplankton during the polar night. J. Phycol. 54, 461-470 (2018).

159. McMinn, A. \& Martin, A. Dark survival in a warming world. Proc. Biol. Sci. 280, 20122909 (2013).

160. Joli, N., Monier, A., Logares, R. \& Lovejoy, C. Seasonal patterns in Arctic prasinophytes and inferred ecology of Bathycoccus unveiled in an Arctic winter metagenome. ISME J. 11, 13727 (2017).

161. Vader, A., Marquardt, M., Meshram, A. R. \& Gabrielsen, T. M. Key Arctic phototrophs are widespread in the polar night. Polar Biol. 38, 13-21 (2015).

162. McMinn, A. \& Martin, A. Dark survival in a warming world. Proc. Biol. Sci. 280, 20122909 (2013).

163. van de Poll, W., Abdullah, E., Visser, R., Fischer, P. \& Buma, A. Taxon-specific dark survival of diatoms and flagellates affects Arctic phytoplankton composition during the polar night and early spring. Limnol. Oceanogr. 65, 903-914 (2019).

164. Boyd, P. W., Lennartz, S. T., Glover, D. M. \& Doney, S. C. Biological ramifications of climate-change-mediated oceanic multi-stressors. Nat. Clim. Change 5, 71-79 (2014).

165. Bopp, L. et al. Multiple stressors of ocean ecosystems in the 21st century: projections with CMIP5 models. Biogeosciences 10, 6225-6245 (2013)

166. Vancoppenolle, M. et al. Future Arctic Ocean primary productivity from CMIP5 simulations: uncertain outcome, but consistent mechanisms. Glob. Biogeochem. Cycle 27, 605-619 (2013).

167. Tedesco, L., Vichi, M. \& Scoccimarro, E. Sea-ice algal phenology in a warmer Arctic. Sci. Adv. 5, eaav4830 (2019)

168. Babin, M. et al. Estimation of primary production in the Arctic Ocean using ocean colour remote sensing and coupled physical-biological models: strengths, limitations and how they compare. Prog. Oceanogr. 139, 197-220 (2015).

169. Lacour, T., Larivière, J. \& Babin, M. Growth, Chl $a$ content, photosynthesis, and elemental composition in polar and temperate microalgae. Limnol. Oceanogr. 201, 43-58 (2016)

170. Lacour, T. et al. The role of sustained photoprotective non-photochemical quenching in low temperature and high light acclimation in the bloom-forming Arctic diatom Thalassiosira gravida. Front. Mar. Sci. 5, 354 (2018).

171. Graham, R. M. et al. Winter storms accelerate the demise of sea ice in the Atlantic sector of the Arctic Ocean. Sci. Rep. 9, 9222 (2019).

172. Berge, J. et al. Unexpected levels of biological activity during the polar night offer new perspectives on a warming Arctic. Curr. Biol. 25, 2555-2561 (2015).

173. Berge, J. et al. In the dark: a review of ecosystem processes during the Arctic polar night. Prog. Oceanogr. 139, 258-271 (2015).

174. Kipp, L. E., Charette, M. A., Moore, W. S., Henderson, P. B. \& Rigor, I. G. Increased fluxes of shelf-derived materials to the central Arctic Ocean. Sci. Adv. 4, eaao1302 (2018).

175. Abram, N. J. et al. Early onset of industrial-era warming across the oceans and continents. Nature 536, 411 (2016).

176. Osman, M. B. et al. Industrial-era decline in subarctic Atlantic productivity. Nature 569, 551-555 (2019).

177. Barton, A. D., Irwin, A. J., Finkel, Z. V. \& Stock, C. A. Anthropogenic climate change drives shift and shuffle in North Atlantic phytoplankton communities. Proc. Natl Acad. Sci. USA 113, 2964-2969 (2016).

178. Rahmstorf, S. et al. Exceptional twentieth-century slowdown in Atlantic Ocean overturning circulation. Nat. Clim. Change 5, 475-480 (2015).

179. Caesar, L., Rahmstorf, S., Robinson, A., Feulner, G. \& Saba, V. Observed fingerprint of a weakening Atlantic Ocean overturning circulation. Nature 556, 191-196 (2018).
180. Thornalley, D. J. R. et al. Anomalously weak Labrador Sea convection and Atlantic overturning during the past 150 years. Nature 556, 227-230 (2018).

181. Moore, J. K. et al. Sustained climate warming drives declining marine biological productivity. Science 359, 1139-1143 (2018).

182. Bakker, P. et al. Fate of the Atlantic Meridional Overturning Circulation: strong decline under continued warming and Greenland melting. Geophys. Res. Lett. 43, 12,252-12,260 (2016).

183. Takahashi, T. et al. Climatological mean and decadal change in surface ocean $\mathrm{pCO}_{2}$, and net sea-air CO2 flux over the global oceans. Deep Sea Res. Pt 2 56, 554-577 (2009).

184. Stock, C. A. et al. Reconciling fisheries catch and ocean productivity. Proc. Natl Acad. Sci. USA 114, E1441-E1449 (2017).

185. Cavalieri, D. J., Parkinson, C., Gloersen, P. \& Zwally, H. J. Sea Ice Concentrations From Nimbus-7 SMMR and DMSP SSM/I Passive Microwave Data Version 1 (NASA National Snow and Ice Data Center Distributed Active Archive Center, 1996); https://nsidc.org/data/NSIDC-0051/versions/1

186. Tschudi, M., Meier, W. N., Stewart, J. S., Fowler, C. \& Maslanik, J. EASE-Grid Sea Ice Age Version 4 (NASA National Snow and Ice Data Center Distributed Active Archive Center, 2019); https://doi.org/10.5067/ UTAV7490FEPB

187. Anderson, L. G. \& Macdonald, R. W. Observing the Arctic Ocean carbon cycle in a changing environment. Polar Res. 34, 26891 (2015).

188. Horner, R. \& Schrader, G. C. Contributions of ice Algae, phytoplankton, and benthic microalgae to primary production in nearshore regions of the Beaufort Sea. Arctic 35, 485-503 (1982).

189. Mundy, C. J. et al. Contribution of under-ice primary production to an ice-edge upwelling phytoplankton bloom in the Canadian Beaufort Sea. Geophys. Res. Lett. 36, L17601 (2009).

190. Oziel, L. et al. Environmental factors influencing the seasonal dynamics of under-ice spring blooms in Baffin Bay. Elem. Sci. Anth. 7, 34 (2019).

191. Ferland, J., Gosselin, M. \& Starr, M. Environmental control of summer primary production in the Hudson Bay system: the role of stratification. J. Mar. Syst. 88, 385-400 (2011).

192. Lalande, C., Nöthig, E. M. \& Fortier, L. Algal export in the Arctic Ocean in times of global warming. Geophys. Res. Lett. 46, 5959-5967 (2019).

193. Lalande, C., Grebmeier, J. M., Hopcroft, R. R. \& Danielson, S. L. Annual cycle of export fluxes of biogenic matter near Hanna Shoal in the northeast Chukchi Sea. Deep Sea Res. Pt 2 177, 104730 (2020).

194. Silkin, V., Pautova, L., Giordano, M., Kravchishina, M. \& Artemiev, V. Interannual variability of Emiliania huxleyi blooms in the Barents Sea: in situ data 2014-2018. Mar. Pollut. Bull. 158, 111392 (2020).

\section{Acknowledgements}

M.A. was supported by a European Union's Horizon 2020 Marie Sklodowska-Curie grant (no. 746748). This work represents a contribution to the Sorbonne Université and Stanford University. We thank M. Gosselin, M. Poulin and E. Leu for sharing their expertize on phytoplankton ecology and taxonomy; M. Nicolaus and W. Meier for sharing their expertize on sea-ice; and L. Oziel and the whole Arrigo's laboratory for insightful comments on the Review.

\section{Author contributions}

M.A. and K.R.A. conceptualized and wrote the manuscript together.

\section{Competing interests}

The authors declare no competing interests.

\section{Additional information \\ Correspondence should be addressed to M.A.}

Reprints and permissions information is available at www.nature.com/reprints.

Publisher's note Springer Nature remains neutral with regard to jurisdictional claims in published maps and institutional affiliations.

(c) Springer Nature Limited 2020 